\title{
ÁRPÁD-KORI TELEPÜLÉSRÉSZLET HÁZAI ÉS TELEPÜLÉSSZERKEZETE JÁSZFÉNYSZARU HATÁRÁBAN
}

\author{
BÍRÓ GYÖNGYVÉR*
}

\begin{abstract}
Part of an Árpádian Age settlement was uncovered at Jászfényszaru-Szőlök alja in 2007. An earlier (11th century-turn of the 12th/13th centuries) and a later (turn of the 12th/13th centuries-14th century) occupation layer could be distinguished. A plot boundary, several rows of houses and a street could be distinguished in the settlement.
\end{abstract}

Keywords: Jászság, Árpádian Age, building, settlement layout, GIS

Jászfényszaru-Szőlók alján 2007-ben egy Árpád-kori település részletét tárták fel. A falu életében egy korábbi (11. század - 12-13. század fordulója) és egy későbbi (12-13. század fordulója - 14. század eleje) periódust lehetett elkülöníteni. A településen egy telekhatár, több házsor és egy utca is kirajzolódni látszik.

Kulcsszavak: Jászság, Árpád-kor, épület, településszerkezet, térinformatika

\begin{abstract}
A Jászfényszaru északkeleti határában található Szőlők alján 2007-ben végeztek megelőző feltárást a szolnoki Damjanich János Múzeum munkatársai Kertész Róbert vezetésével. ${ }^{1}$ A több mint $30000 \mathrm{~m}^{2}$ nagyságú ásatási területen 309 objektumot tártak fel (1. kép); többségük egy Árpád-kori településhez tartozott. Jelen dolgozat az itt feltárt épületeket és egyéb telepjelenségeket (külső kemencék, karámok, árokrendszerek) mutatja be, majd összegzi a településszerkezetre és annak változásaira vonatkozó adatokat.
\end{abstract}

\footnotetext{
A kézirat érkezett: 2015. március 27.

* Bíró Gyöngyvér. Szántó Kovács János Területi Múzeum, 5900 Orosháza, Dózsa György u. 5.; Pf. 73. gyongyver.br@gmail.com

1 Köszönöm dr. Kertész Róbertnek, hogy mint ásatásvezetó a Szőlők alja lelőhelyen feltárt leletanyagot feldolgozásra és közlésre átengedte. A feldolgozásban nyújtott segítségéért és hasznos tanácsaiért köszönettel tartozom dr. Wolf Máriának.
}

\section{Középkori települések Jászfényszaru területén}

Jászfényszaru folyóvizei nagyban meghatározták a települési viszonyokat. A vizenyősebb, áradások alkalmával víz alá kerüló területekból kiemelkedő homokhátak több évezreden keresztül megfelelőnek bizonyultak az emberi megtelepedésre, ahogyan erre a lelóhelyek viszonylag magas számából is következtethetünk. A mai Jászfényszaru területén név szerint eddig két, írott forrásokból ismert középkori település azonosítására tettek kísérletet. Magának Fényszarunak a neve legkorábban Fennuszaru alakban tünik fel Zsigmond király 1433. évi oklevelében. ${ }^{2}$ Az Árpád-kori Fényszarut Selmeczi László előbb Jászfényszaru-Barátok tava, majd Homokszállás

2 MOL Df. 210120 E. „Parancs Négyszállási Kompolthoz és Fényszarui Lukácshoz, hogy az elfoglalt Szentandrást adják vissza az egri káptalan urainak." FodOR 1942, 361; BENEDEKZÁDORNÉ ZSOLDOS 1998, 63, 72. 


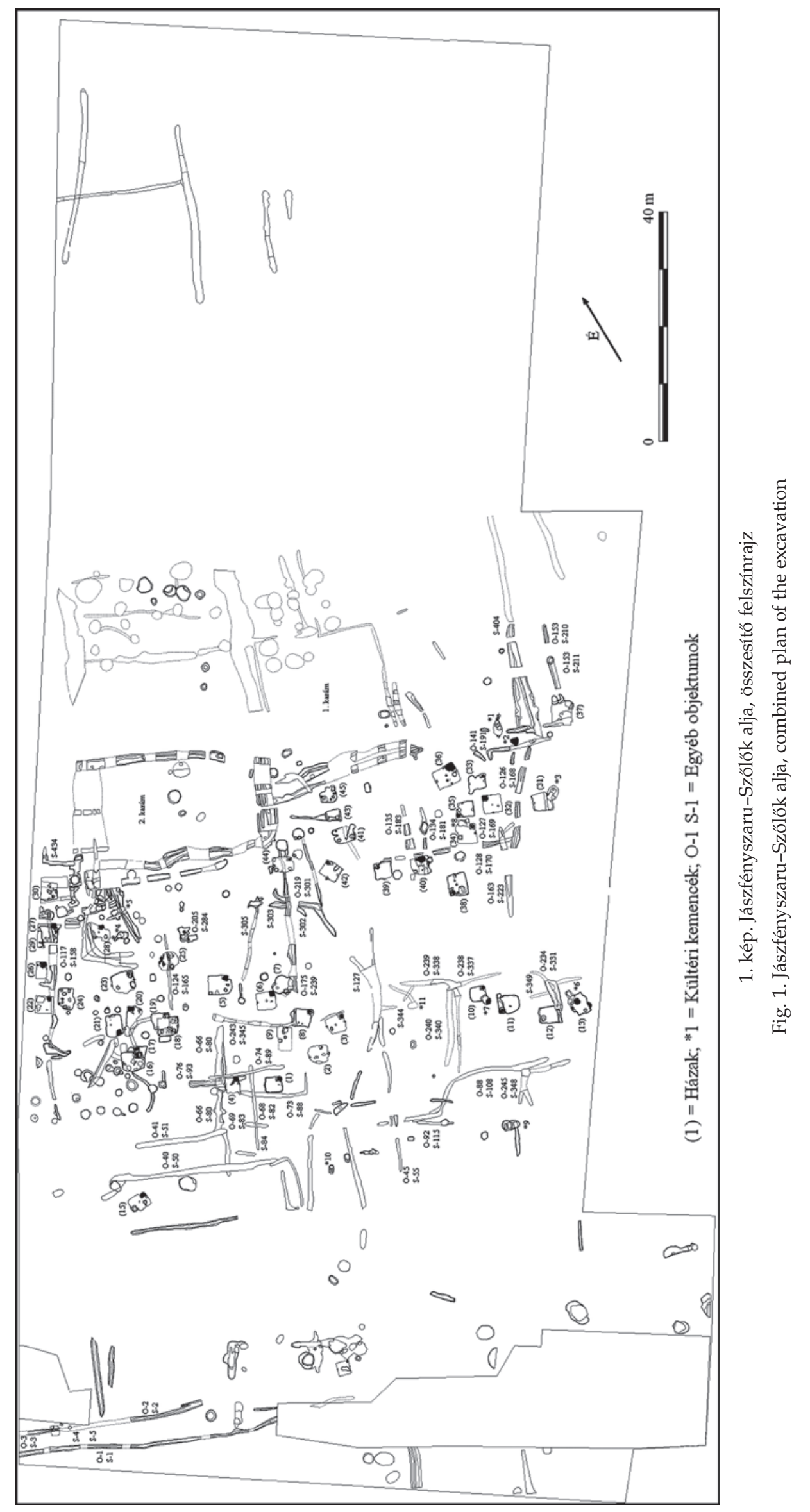


lelóhellyel hozta kapcsolatba. ${ }^{3}$ Szintén Selmeczi lokalizálta sikeresen egy ásatás során Szentkozmadamján-szállást a mai Jászfényszaru Kozma-part/Kozma-domb névvel illetett részén. ${ }^{4}$ Ha nem is kapcsolhatók össze a forrásokban felbukkanó helységnevekkel, más településekre utaló lelóhelyek is ismertek erról a területről a középkor időszakából. A terepbejárások alkalmával talált kerámialeletek alapján több 1113. századi települést is valószínúsíteni lehetett a mai Jászfényszaru területén. ${ }^{5}$ A Szőlők alján feltárt településrészlet az előbb említett Kozmapart és a Barátok tava között helyezkedik el (2. kép 1).

A ma már alig látható és kevéssé jelentősnek tartott, 1-5 méteres szintkülönbségek, tereplépcsők különböző gazdálkodást, településrendet, életformát tettek lehetővé. ${ }^{6} \mathrm{~A}$ most tárgyalt település is egy ilyen homokháton terült el, amelynek legmagasabb pontja és az azt övezó mélyebb területek között 2,7 m volt a szintkülönbség (3. kép). A folyószabályozások, ármentesítések nagyban befolyásolták az alföldi területek vízrajzát, talajvízszintjét és a belvíz megjelenésének valószínúségét. ${ }^{7}$ Ezen változások negatív hatását a 2007-ben végzett ásatás során is érzékelni lehetett: a szelvény északi, illetve déli részein összegyúlt talaj- és belvíz miatt az itt található objektumok nem vagy csak részben kerültek kibontásra. Továbbá lehettek olyan régészeti jelenségek, amelyek a körülmények miatt nem váltak láthatóvá.

\section{A Szőlook alján feltárt település kiterjedése}

A feltárási szelvény széle nyugaton több házat is félbevágott, így bizonyos, hogy a telep még folytatódik ebben az irányban (1. kép). A terület délnyugati szélén árokrendszerek húzódnak. Ezek némileg elkülönülnek a többi objektumtól, talán már a telep határát jelezhetik. Északi irányban árkok és gödrök találhatók a feltárt felszín peremén, de ezek is 15-20 méterrel távolabb helyezkednek el a centrumtól. Utóbbi objektumok kibontására a talaj-, illetve belvíz miatt sok esetben nem volt lehetőség. A telepet keleti-délkeleti irányból gyárterület határolja. 2012 őszén a 2007es ásatási szelvénytől nyugatra eső szántóföldön, továbbá a délról szomszédos homokháton (ma szintén mezőgazdasági terület), az Ószőlők II.

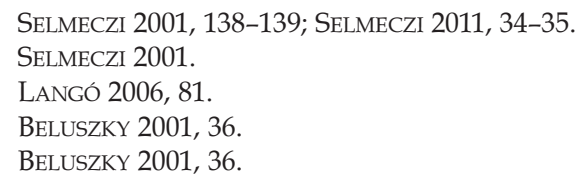

elnevezésú lelóhelyen történt terepbejárás (2. kép 1). A felszín átvizsgálása során talált késő Árpádkori, illetve esetenként már a 14. századra utaló kerámiatöredékek ${ }^{8}$ megerősítették a feltevést, miszerint a falu egy része még feltáratlan. Ószőlők II. lelőhelyet csupán egy keskeny, a közelmúltban mesterségesen kialakított ér választja el Szőlők aljától, a két terület korábban tehát érintkezett egymással. Feltételezhető, hogy Ószőlők II. és Szőloók alja esetleg ugyanazon település nyomait őrzi, de legalábbis az Árpád-kor végén mindkét terület lakott volt.

\section{Az Árpád-kori településrészlet}

A Szőlők alján feltárt 309 objektum többsége gödör és árok volt. Elhelyezkedése, szerkezete, valamint leletanyaga alapján 44 ház köthetó biztosan az Árpád-kori településhez. ${ }^{9}$ A 44 épület mellett 11 szabadtéri kemence és 2 karámként értelmezhető építmény nyoma is napvilágot látott.

A leletanyagban a kerámia dominál (két edényt leszámítva csak töredékek). Néhány objektumban kőeszközöket (pl. fenőkő, őrlőkő) és állatcsontokat (is) találtak, azonban - mint az Árpádkori falvak többségében - fémleletek igen csekély számban kerültek elő. Az épületek leletei között csupán egyetlen, keltező értékkel bíró fémtárgyat lehet megemlíteni, egy gúla alakú tüskével ellátott, ívelt szárú sarkantyút. Egy vas hátlapból és réz előlapból álló gomb (?) szintén szerepel a leletek között; rajta domború minta látható. Ez azonban egyelőre analógia nélküli, így a datálásban nem segít.

Az egyes objektumok között fennálló szuperpozíciók lehetóséget adtak egy relatív kronológia kidolgozására, amely alapján már a kutatás kezdetén világossá vált, hogy az Árpád-koron belül is több periódussal számolhatunk. A relatív időrend finomításában a leletanyag összetételéból adódóan jóformán csak a kerámiára lehetett építeni.

A település korai időszakára (11. század12. század második fele) a homokos anyagú, vörösre, barnára, esetleg feketére égetett, érdes tapintású kerámia volt jellemző, amely fóként gömbölyded formájú, egyszerú, enyhén kihajló peremmel ellátott fazekak formájában mutatkozik meg a leletanyagban, de elvétve tárolóedény-

8 A 2012-ben Langó Péterrel közösen végzett terepbejárás során őskori, szarmata és újkori kerámiatöredékeket is találtunk.

9 A 14. számú ház leletanyaga alapján nem Árpád-kori. Jóval korábbra keltezhető, és el is különült a többi házcsoporttól, ezért elemzésére itt nem kerül sor. 

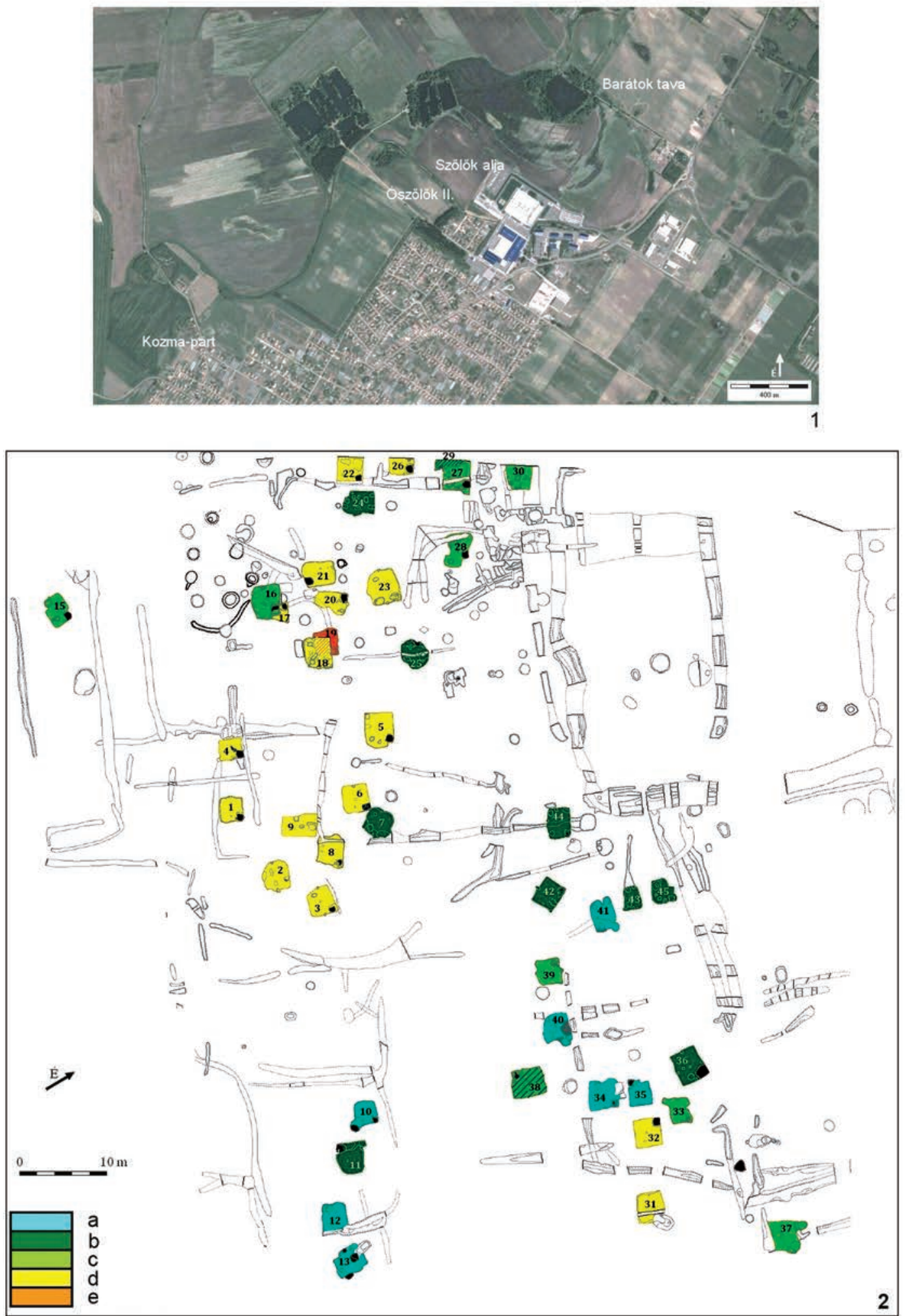

2. kép. 1: Középkori lelőhelyek: Kozma-part, Ószőlők II., Barátok tava; 2: Az Árpád-kori település korai, átmeneti és kései periódusainak épületei. a: nem keltezhetố pontosan; b: 12-13. század fordulója-14. század eleje; c: 12. század vége-13. század eleje; d-e: 11. század-12. század második fele

Fig. 2. 1: Medieval sites: Kozma-part, Ószólők II, Barátok tava; 2. Buildings of the early, the transitional and the late occupation of the Árpádian Age site. a: uncertain date; b: turn of the $12^{\text {th }}-13^{\text {th }}$ century-beginning of the $14^{\text {th }}$ century; c: end of the $12^{\text {th }}$ century-beginning of the $13^{\text {th }}$ century; d-e: $11^{\text {th }}$ century-second half of the $12^{\text {th }}$ century 
és palacktöredék is előfordul. Leginkább a korai kerámiákra jellemző a hullámvonal- és/vagy vonalköteg minta. A díszítési formák többsége azonban folyamatosan jelen van, így a fazekak és tárolóedények vállán látható, íves bekarcolások, a vonaldísz és a fogaskerék minta a korábbi és későbbi töredékeken egyaránt megfigyelhetők. A korai és a kései periódus között fokozatos átmenetet tapasztaltunk. Korábban helyi eredetú, mészben gazdag nyersanyagot használtak, amelynél mesterséges soványításra utaló nyomot nem találtunk. A 12-13. század fordulójától kezdve viszont egy másfajta, mészben szegényebb, a közvetlen földtani környezettől idegen törmelékszemcsékkel soványított agyagot alkalmaztak. ${ }^{10}$ Az ebból készített edények szabad szemmel látható jellegzetessége a fehér, szürkés- vagy sárgásfehér, illetve bézs szín és a nagyméretú törmelékszemcsék soványítóanyagként való felhasználása. A kései periódus (12-13. század-14. század eleje) nyersanyaga tehát élesen elüt a korábbitól, de az edények típusai és formái csak fokozatosan változtak meg. Az új típusú agyagból készített fazekak nyúlánkak, vállban öblösödnek, peremük formája változatos, gyakran élesen tagolt, leggyakoribb díszítésük pedig a csigavonal. Ezeken a fazekakon, fazéktöredékeken olykor fenékbélyegek is megfigyelhetők. ${ }^{11}$ A nagyméretú tárolóedények, palackok és bográcsok töredékei szintén megjelennek a fazekak mellett az átmeneti időszak és a kései periódus leletanyagában. A legkésőbbi példányok között már fedőhoronnyal ellátott fazékperemek és fedő-peremtöredékek is találhatók. Néhány vékony falú, finom anyagú peremtöredék akár kisebb tálhoz is tartozhatott.

A szuperpozíciók és a leletanyag alapján a 19. ház bizonyult az egyik legkorábbinak, továbbá az 1-6., 8-9., 17-18., 20-23., 26. és a 31-32. házakat lehetett a korábbi periódusra keltezni (11. század-12. század második fele) (2. kép 2). ${ }^{12} \mathrm{Az}$ átmeneti időszak (12. század vége-13. század eleje) épületei a 15-16., 27-28., 30., 33., 37. és a 39. ház. Idesorolható továbbá a 29. és a 38. ház is, de ezek már inkább a 13. századi épületek közé tartoznak. A település kései időszakához (12-13. század fordulója-14. század eleje) köthetók a 7., 11., 24-25., 36. és a 42-45. házak. Nem rendelkezett leletanyaggal, így ez alapján pontosabban nem is keltezhetó a 10., 12-13., 31., 34-35. és a 4041. ház. Ezek korszakolásában némiképp majd

10 BírÓ-Fintor-RAUCSIK-WOLF-Tóth 2013, 27, 37.

11 Bíró 2015.

12 Az épületek leletanyagának részletes elemzése és keltezése: BíRó 2014, 118-126. segítenek a jelen dolgozatban ismertetett egyéb objektumok.

Adataink szerint az élet folyamatos volt a faluban. A kerámiaanyagban megfigyelhetó átalakulás, bizonyos díszítésmódok továbbélése, a főbb edénytípusok változatlan jelenléte, alakjuk fokozatos változása arra utal, hogy mindvégig ugyanaz a népesség élt itt. Ezt a feltevést erősítik meg néhány esetben a házak megújításának nyomai.

\section{Épületek}

Az alábbiakban - a 44 Árpád-kori épület egyenként történő bemutatása nélkül - a házaknál tapasztalható főbb jellemzőket, főként a szerkezetre, tetőre, falazatra, bejáratra, padlóra, tüzelőberendezésre utaló jelenségeket ismertetem. Az egyes házak adatait az 1. táblázat tartalmazza.

A jászfényszarui feltáráson - mint a legtöbb Árpád-kori településásatáson - házgödröket, oszlophelyeket, tüzelőberendezéseket és kisebbnagyobb gödröket lehetett megfigyelni az épületeken belül. Mivel a területen az ásatást megelözően mezőgazdasági tevékenység folyt, illetve gépi humuszolást végeztek, nem ismerjük az eredeti járószintet, így nem lehet meghatározni a földbe ásott objektumok eredeti mélységét sem. A házakra több esetben csak pár centiméteres relatív mélységú házgödrök utalnak. Ennek fényében földbe nem vagy csak kevéssé mélyített építmények is tartozhattak a településhez, amelyek megfigyelésére az előbb említett okok miatt már nem volt lehetőség. ${ }^{13}$

A házak többnyire téglalap vagy négyzet alaprajzúak, illetve alakjuk az említett külső behatások miatt olykor torzult, szabálytalan formát mutat. Hosszabbik oldaluk 2,5 és 4,6 m között változik (átlagosan 3,42 m), míg rövidebb oldaluk 2,1 és 4,2 m közötti (átlagosan 2,91 m) hosszúságú. Amely házak gödreinek oldalhosszúságait ismerjük, ${ }^{14}$ azoknak az alapterülete megközelítőleg 5,04 és 19,32 m² között határozható meg (átlagosan 9,98 $\left.\mathrm{m}^{2}\right)$, de még a legnagyobb alapterületú ház (16.) gödrének mérete sem mondható túl nagynak. ${ }^{15}$ Az épületek hosszanti tengelye legtöbbször északnyugat-délkeleti vagy északkelet-

13 Eredetileg feltehetően az O-205 S-284 amorf formájú objektum is ház lehetett, amelynek már csak mélyebb részleteit sikerült feltárni.

14 Nem minden esetben volt lehetőség az egykori épület teljes alapterületének megfigyelésére (pl. 9. ház).

15 Sabján Tibor rekonstrukciója alapján a feltárt házgödrök méreténél nagyobb alapterülettel számolhatnánk, amennyiben a jászfényszarui házakat egyértelmúen veremházként lehetne meghatározni (SABJÁN 1999, 133-139). 
1. táblázat. A házak adatai

Table 1. Data of the houses

\begin{tabular}{|c|c|c|c|c|c|c|c|c|c|c|}
\hline $\begin{array}{c}\text { Ház } \\
\text { sorszáma }\end{array}$ & $\begin{array}{l}\text { Hosszabbik } \\
\text { oldal } \\
(\mathrm{m})\end{array}$ & $\begin{array}{c}\text { Rövidebb } \\
\text { oldal } \\
\text { (m) }\end{array}$ & $\begin{array}{c}\text { Alapterület } \\
\left(\mathrm{m}^{2}\right)\end{array}$ & $\begin{array}{l}\text { Relatív } \\
\text { mélység } \\
(\mathrm{cm})\end{array}$ & $\begin{array}{c}\text { Maximum } \\
\text { mélység } \\
(\mathrm{cm})\end{array}$ & Kemence & $\begin{array}{l}\text { Kemence } \\
\text { helye }\end{array}$ & Bejárat & $\begin{array}{l}\text { Bejárat } \\
\text { helye }\end{array}$ & Ház betöltése \\
\hline 1. ház & 3 & 2,8 & 8,4 & 20 & 20 & $\mathrm{~T}$ & ÉK & - & - & $\mathrm{H}, \mathrm{P}$ \\
\hline 2. ház & 3,5 & 2,3 & 8,05 & 15 & 15 & $?$ & ÉK & - & - & $\mathrm{H}$ \\
\hline 3. ház & 3,1 & 3 & 9,3 & $0-10$ & 10 & $\mathrm{~T}$ & ÉNy & - & - & - \\
\hline 4. ház & 2,6 & 2,5 & 6,5 & $25-30$ & 30 & $\mathrm{~T}$ & ÉK & - & - & $\mathrm{A}$ \\
\hline 5. ház & 4,2 & 3,4 & 14,28 & $10-15$ & 15 & $\mathrm{~T}$ & ÉK & - & - & $\mathrm{O}$ \\
\hline 6. ház & 3,5 & 3 & 10,5 & $5-20$ & 20 & $\mathrm{~T}$ & ÉK & - & - & - \\
\hline 7. ház & 3,6 & 3,1 & 11,16 & 15 & 15 & $\mathrm{~T}, \mathrm{~K}$ & ÉK & - & - & $\mathrm{O}$ \\
\hline 8. ház & 3,1 & 3 & 9,3 & $5-10$ & 10 & $\mathrm{~T}$ & ÉK & - & - & $\mathrm{O}$ \\
\hline 9. ház & 4,2 & 2,6 & 10,92 & $?$ & $?$ & $\mathrm{~T}$ & ÉK & - & - & - \\
\hline 10. ház & 3 & 2,8 & 8,4 & 17 & 17 & $\mathrm{~T}$ & ÉK & $\mathrm{M}$ & DNy & $\mathrm{P}$ \\
\hline 11. ház & 3,6 & 3 & 10,8 & 15 & 15 & $\mathrm{~T}$ & ÉK & $M$ & DNy & $\mathrm{P}$ \\
\hline 12. ház & 3,7 & 3 & 11,1 & 18 & 18 & $\mathrm{~T}$ & ÉK & $\mathrm{M}$ & ÉNy & É \\
\hline 13. ház & 3,4 & 3,3 & 11,22 & $10-18$ & 18 & $\mathrm{~T}$ & DK & $\mathrm{M}$ & DNy & É \\
\hline 15. ház & 3,5 & 2,7 & 9,45 & $5-20$ & 20 & $\mathrm{~T}$ & ÉK & $\mathrm{M}$ & DNy & $\mathrm{P}$ \\
\hline 16. ház & 4,6 & 4,2 & 19,32 & $20-30$ & 30 & $\mathrm{~T}$ & ÉK & $\mathrm{M}$ & ÉNy & $\mathrm{O}$ \\
\hline 17. ház & 2,4 & 2,1 & 5,04 & 7 & 7 & $\mathrm{~T}$ & É & - & - & - \\
\hline 18. ház & 3,8 & 3,1 & 11,78 & $8-10$ & 10 & $\mathrm{~T}$ & $\mathrm{~K}$ & - & - & - \\
\hline 19. ház & 3,2 & 2,9 & 9,28 & $15-20$ & 20 & $\mathrm{~T}$ & $\mathrm{~K}$ & - & - & - \\
\hline 20. ház & 3,6 & 2,7 & 9,72 & $5-15$ & 15 & $\mathrm{~T}$ & É & - & - & $\mathrm{O}, \mathrm{P}$ \\
\hline 21. ház & 3,6 & 2,9 & 10,44 & 15 & 15 & $\mathrm{~T}$ & DK & - & - & - \\
\hline 22. ház & 3,2 & 2,9 & 9,28 & 20 & 20 & $\mathrm{~T}$ & ÉK & - & - & - \\
\hline 23. ház & 4,2 & 3,5 & 14,7 & $5-20$ & 20 & $\mathrm{~T}$ & ÉK & - & - & $\mathrm{P}$ \\
\hline 24. ház & 3,6 & 2,7 & 9,72 & $10-20$ & 20 & $?$ & $?$ & - & - & - \\
\hline 25. ház & 3,5 & 2,8 & 9,8 & $5-25$ & 25 & $?$ & ÉK & - & - & - \\
\hline 26. ház & $?$ & 2,8 & $?$ & $10-12$ & 12 & $\mathrm{~T}$ & ÉK & - & - & - \\
\hline 27. ház & 3,2 & 2,9 & 9,28 & 20 & 20 & $\mathrm{~T}$ & ÉK & - & - & - \\
\hline 28. ház & 4,05 & 2,9 & 11,745 & $20-30$ & 30 & $\mathrm{~T}$ & ÉK & - & - & - \\
\hline 29. ház & $?$ & 3,5 & $?$ & 30 & 30 & $\mathrm{~T}$ & ÉK & - & - & $\mathrm{O}, \mathrm{H}$ \\
\hline 30. ház & $?$ & 3,2 & $?$ & $?$ & $?$ & - & - & - & - & - \\
\hline 31. ház & 3,4 & 3,2 & 10,88 & $35-40$ & 40 & $\mathrm{~T}$ & É & - & - & $\dot{E}$ \\
\hline 32. ház & 3,2 & 2,9 & 9,28 & 20 & 20 & $\mathrm{~T}, \mathrm{~K}$ & ÉNy & - & - & $\mathrm{A}$ \\
\hline 33. ház & 2,9 & 2,4 & 6,96 & 20 & 20 & $\mathrm{~T}, \mathrm{~K}$ & ÉK & $?$ & DNy & - \\
\hline 34. ház & 3,3 & 3,3 & 10,89 & 20 & 20 & $\mathrm{~T}$ & ÉK & - & - & - \\
\hline 35. ház & 3,2 & 2,7 & 8,64 & 10 & 10 & $\mathrm{~T}$ & ÉK & - & - & - \\
\hline 36. ház & 4,2 & 3 & 12,6 & $10-15$ & 15 & $?$ & ÉK & - & - & - \\
\hline 37. ház & 4 & 3 & 12 & $15-25$ & 25 & $\mathrm{~T}$ & ÉK & - & - & - \\
\hline 38. ház & 3,5 & 3 & 10,5 & $17-22$ & 22 & $\mathrm{~T}$ & $\mathrm{DNy}$ & - & - & $\mathrm{P}, \mathrm{E}, \mathrm{H}$ \\
\hline 39. ház & 2,5 & 2,5 & 6,25 & $8-15$ & 15 & $\mathrm{~T}$ & É & - & - & - \\
\hline 40. ház & 2,5 & 2,5 & 6,25 & $10-15$ & 15 & túzhely & ÉNy & - & - & $\mathrm{O}, \mathrm{P}, \mathrm{E}, \mathrm{H}$ \\
\hline 41. ház & 3,8 & $?$ & $?$ & $?$ & $?$ & $?$ & ÉK & - & - & $\mathrm{A}, \mathrm{O}$ \\
\hline 42. ház & 3,3 & 3,2 & 10,56 & 30 & 30 & $\mathrm{~T}$ & É & - & - & $\mathrm{A}, \mathrm{O}$ \\
\hline 43. ház & 2,9 & 2,6 & 7,54 & $0-3$ & 3 & $?$ & ÉK & - & - & $\mathrm{A}$ \\
\hline 44. ház & 3,7 & 2,5 & 9,25 & $0-5$ & 5 & $\mathrm{~T}, \mathrm{C}$ & ÉK & - & - & $\mathrm{O}$ \\
\hline 45. ház & 2,9 & 2,8 & 8,12 & $0-10$ & 10 & $\mathrm{~T}$ & ÉK & - & - & - \\
\hline
\end{tabular}

Jelmagyarázat

Kemence: $\mathrm{T}$ = tapasztott, $\mathrm{K}$ = a sütőfelület alá köveket helyeztek, $\mathrm{C}=$ a sütőfelületbe kerámiát tapasztottak

Bejárat: $\mathrm{M}=$ meneteles

Betöltés: $\mathrm{H}=$ hamus, $\mathrm{P}=$ paticsos, $\mathrm{A}=$ agyagos, $\mathrm{O}=$ omladékos, $\mathrm{E}=$ égett

A betöltésnél csak a fontosabb jelenségek kerültek kiemelésre. 
délnyugati tájolású. Minden házra igaz, hogy részben földbe mélyítették, de a nyesett felszínhez mérve egyik sem rendelkezett jelentős mélységgel. A legtöbb épületben különböző méretú és mélységú oszlophelyek voltak megfigyelhetők, ezek azonban feltehetően nem minden esetben tartoztak a ház szerkezeti elemei közé. ${ }^{16}$

\section{Szerkezeti megoldások}

Két ágasfa a két rövidebb vagy hosszabb oldalon (1., 2., 4., 10., 11., 13., 15., 20., 23., 26., 31., 33., 34., 35., 39., 43., 44., 45. ház) (4. kép 1) ${ }^{17}$

A leggyakoribb szerkezeti elrendezés a házak két rövidebb oldalának közepén elhelyezett egy-egy oszlop. Ezek feltehetően ágasfák voltak, amelyek a szelemengerendát tartották, tehát az épületeket valószínúleg nyeregtetővel fedték. Az oszlophelyek változó méretúek voltak: 15-50 cm átmérójűek és a padlószinttől számítva 6-80 cm mélyek. A bennük egykor állt oszlopok valódi méretét nem ismerjük. Néhány esetben a házakat metsző objektumok miatt a mélységadatok is esetlegesek. A legtöbb esetben az átmérő és a mélység egyaránt 20-30 cm volt. Csak egy épületnél lehetett megfigyelni egy-egy oszlophelyet a két hoszszabb oldal közepén. Itt az elóbbihez hasonló szerkezettel számolhatunk, viszont ebben az esetben rövidebb volt a tetőt tartó szelemen. A két ágasfás szerkezet az egész Árpád-kor folyamán jelen volt, de a 18 idesorolható épület között a korai házak dominálnak, és csak négy keltezhetô a település kései időszakára. Ehhez hasonló épületek a legtöbb Árpád-kori településen megfigyelhetők, így a párhuzamok felsorolásától eltekintek.

Három ágasfa a ház középtengelyében (3., 6., 16., 18., 32., 38., 40. ház) (4. kép 2)

A három ágasfás szerkezet gyakorlatilag megfelel az előzó szerkezeti elrendezésnek, csupán egy további tartóelemmel bóvül, amely a két ágasfa között, a ház közepén helyezkedik el. Többnyire

16 Például az 1. háznál megfigyelhetô oszlophely éppen a kemence nyílásával szemben található, így helyzete alapján valamilyen szikrafogó alkalmatosságra is gondolhatnánk (WOLF 2001, 133-134; WOLF 2002, 45)

17 A 4., 11., 13., 26., 31., 34. házaknál nem volt tisztán látható a második oszlophely, de az ásatáson tett megfigyelések alapján nagy valószínúséggel ezek is a két ágasfával rendelkező épületek közé tartoztak. A 15. háznál egy harmadik oszlophely meglétét is feltételezték, de ezt nem lehetett egyértelmúen megfigyelni.

A házak fotóit és rajzait a Damjanich János Múzeum munkatársai készítették, az ásatási dokumentáció részét képezik. a hosszabb tengely mentén sorakoznak ezek az oszlophelyek, de például a 32. háznál ennek épp az ellenkezőjét tapasztalhatjuk. A jászfényszarui településen ez a második leggyakoribb házszerkezet. Az előzóhöz hasonlóan ez is jelen volt a korai, az átmeneti és a kései időszakban is. Hasonlót ismerünk például Lébény-Bille-dombról, ${ }^{18}$ Tiszalök-Rázomról ${ }^{19}$ és Tiszaeszlárról. ${ }^{20}$ Tiszaeszláron, ${ }^{21}$ valamint a szeri monostor területén ${ }^{22}$ olyan épületeket is sikerült feltárni, amelyek tengelyében négy oszlop helyezkedett el egy sorban.

Egy vagy két oszlop az egyik rövidebb vagy hosszabb oldalon (5., 7., 8., 17., 25., 41. ház) (4. kép 3)

Az 5. és a 41. háznál az egyik rövidebb, míg a 7., 17., 25. épületeknél az egyik hosszabb oldalon lehetett megfigyelni egy, illetve a 8. háznál egymás mellett két oszlophelyet. Ebben az esetben valamilyen aszimmetrikus kialakítású tetőre gondolhatunk, de az sem kizárható, hogy a szemközti oldalon is volt egy vagy két tartóelem, amely nem hagyott jól dokumentálható nyomot. Utóbbi esetben vagy a két ágasfás szerkezeti elrendezéssel, vagy egy megújított oszloppal számolhatunk. Kronológiailag ez a csoport is vegyes képet mutat: három korai és két kései épületnél lehetett megfigyelni ezt a fajta szerkezetet.

\section{Egy oszlop középen (9. és 37. ház) (5. kép 1)}

Mindössze két esetben lehetett megfigyelni egyetlen oszlophelyet a házgödör közepén. Ez egy másfajta, de a meglévő adatok alapján egyelóre nem rekonstruálható tetőszerkezetre enged következtetni. A 9. a korai, míg a 37. ház az átmeneti periódusra tehető.

Négy oszlop az oldalak közepén és egy középen (30. és 36. ház) (5. kép 2)

Ezt a típust a 36. ház szerkezete szemlélteti a legjobban, de valószínúleg a 30. épület is hasonló elrendezésú. Utóbbinál nehézséget jelent, hogy több késóbbi árok is vágja a házat, így csak a megmaradt négy oszlophely helyzete alapján következtethetünk a 36. épületnél tapasztalhatóhoz hasonló szerkezetre. Ilyen épületeket ismerünk többek között Ménfócsanak-Szeles-dúlőről és

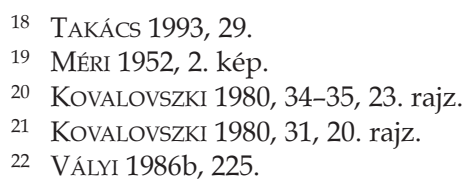




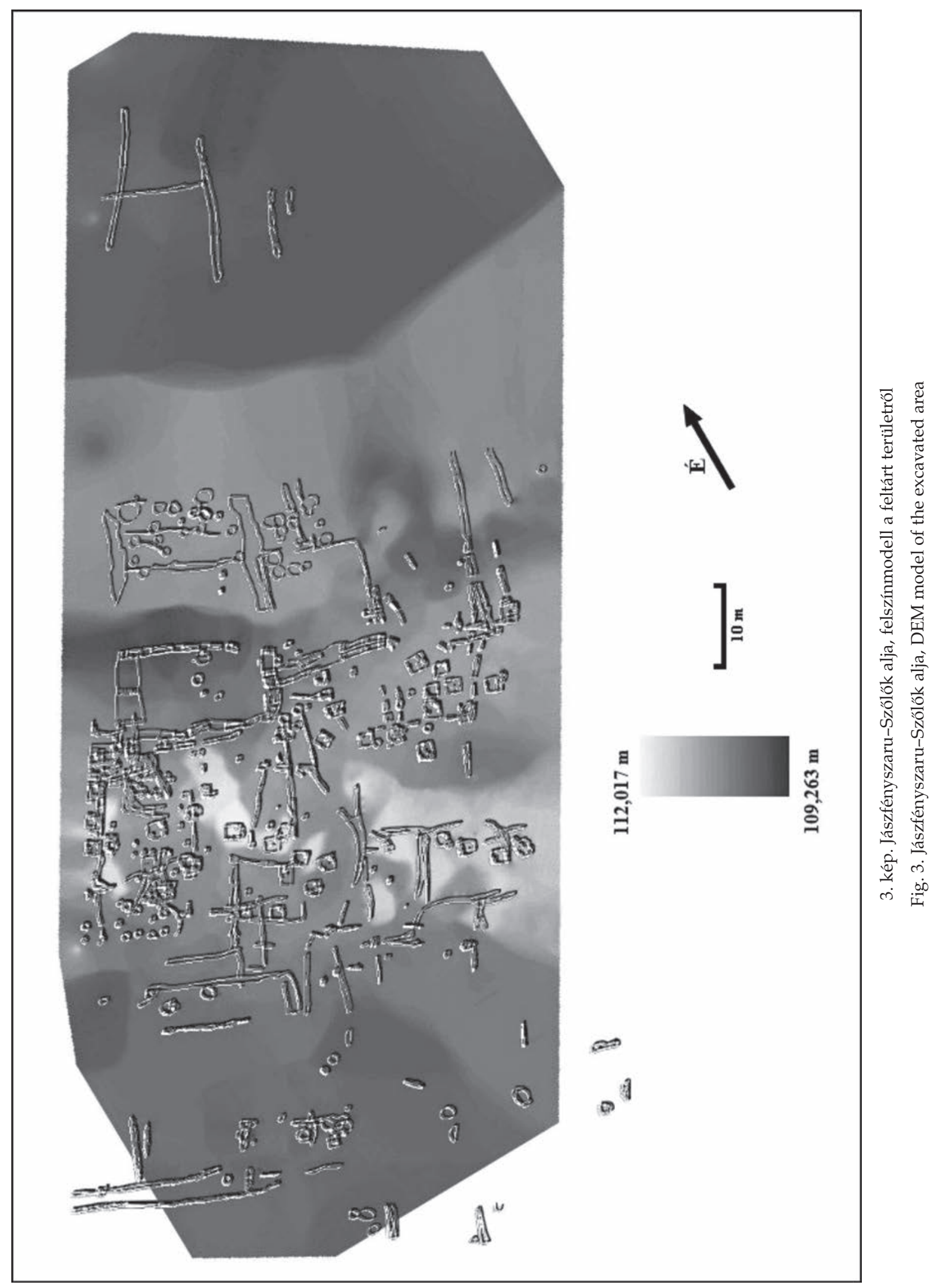




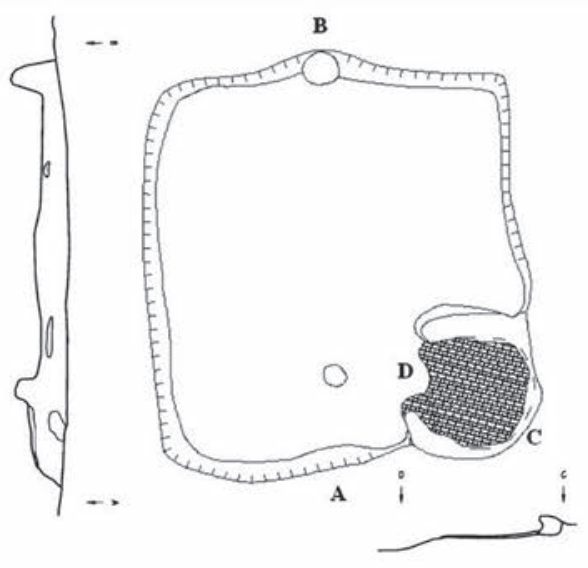

1
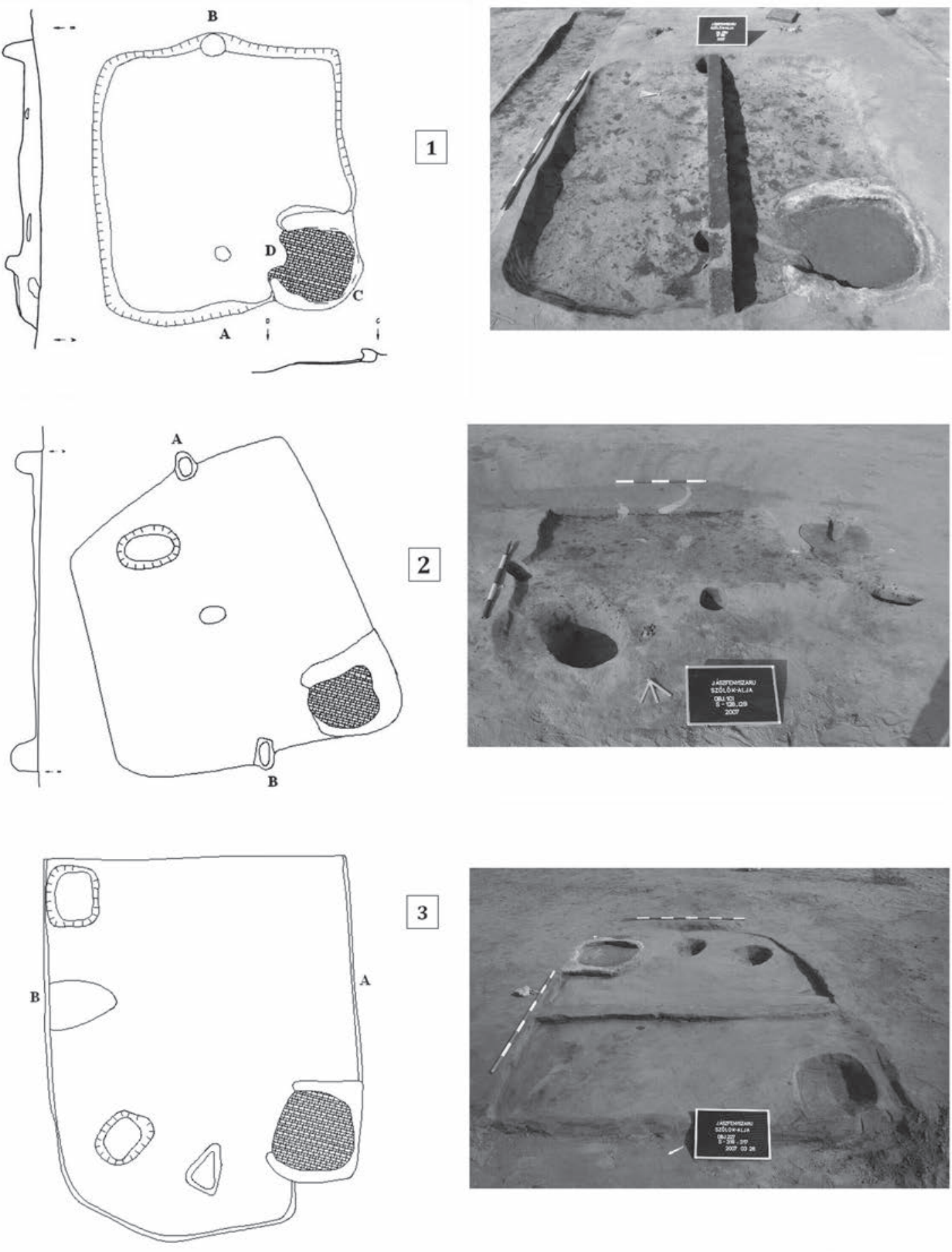

3
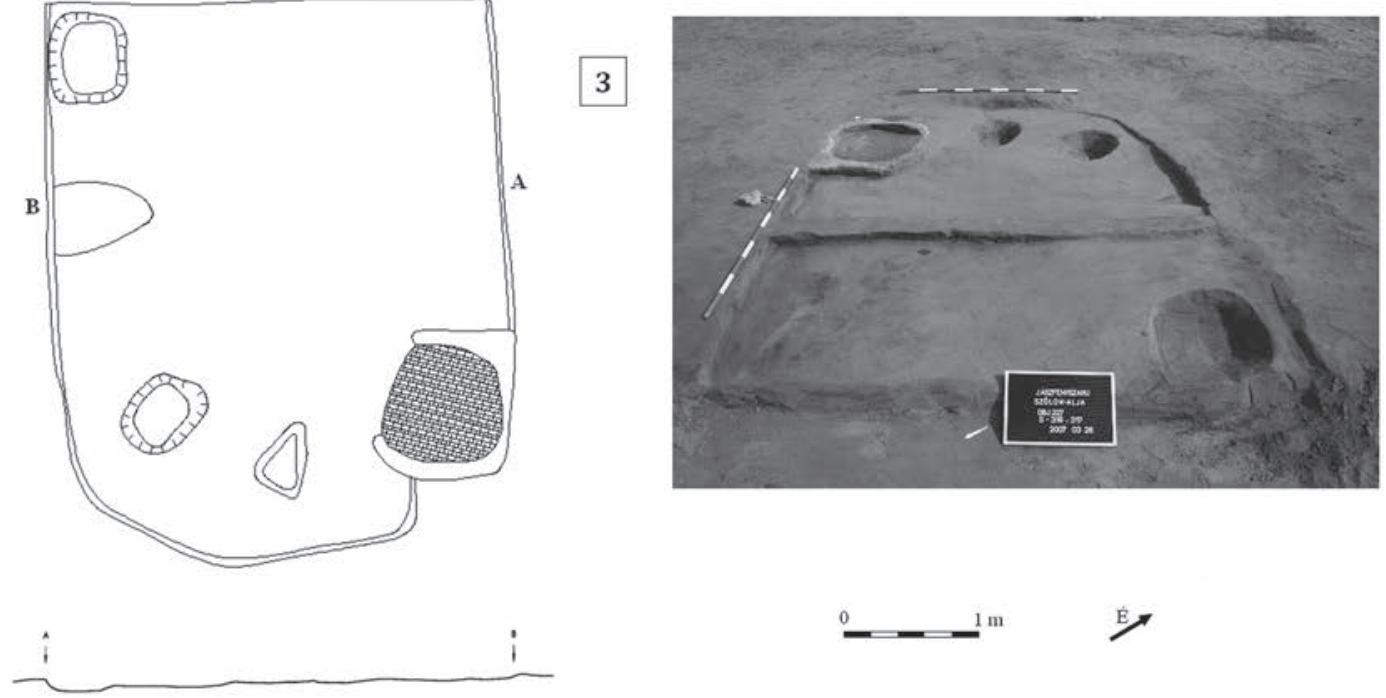

4. kép. Jászfényszaru-Szőlők alja. 1: Két ágasfa a két rövidebb vagy hosszabb oldalon (1. ház); 2: három ágasfa a ház középtengelyében (3. ház); 3: egy vagy két oszlop az egyik rövidebb vagy hosszabb oldalon (5. ház)

Fig. 4. Jászfényszaru-Szőlők alja. 1: Two forked ridge poles on the short or the long side (House 1); 2: three forked ridge poles along the house's axis (House 3); 3: one or two posts along the short or long side (House 5) 


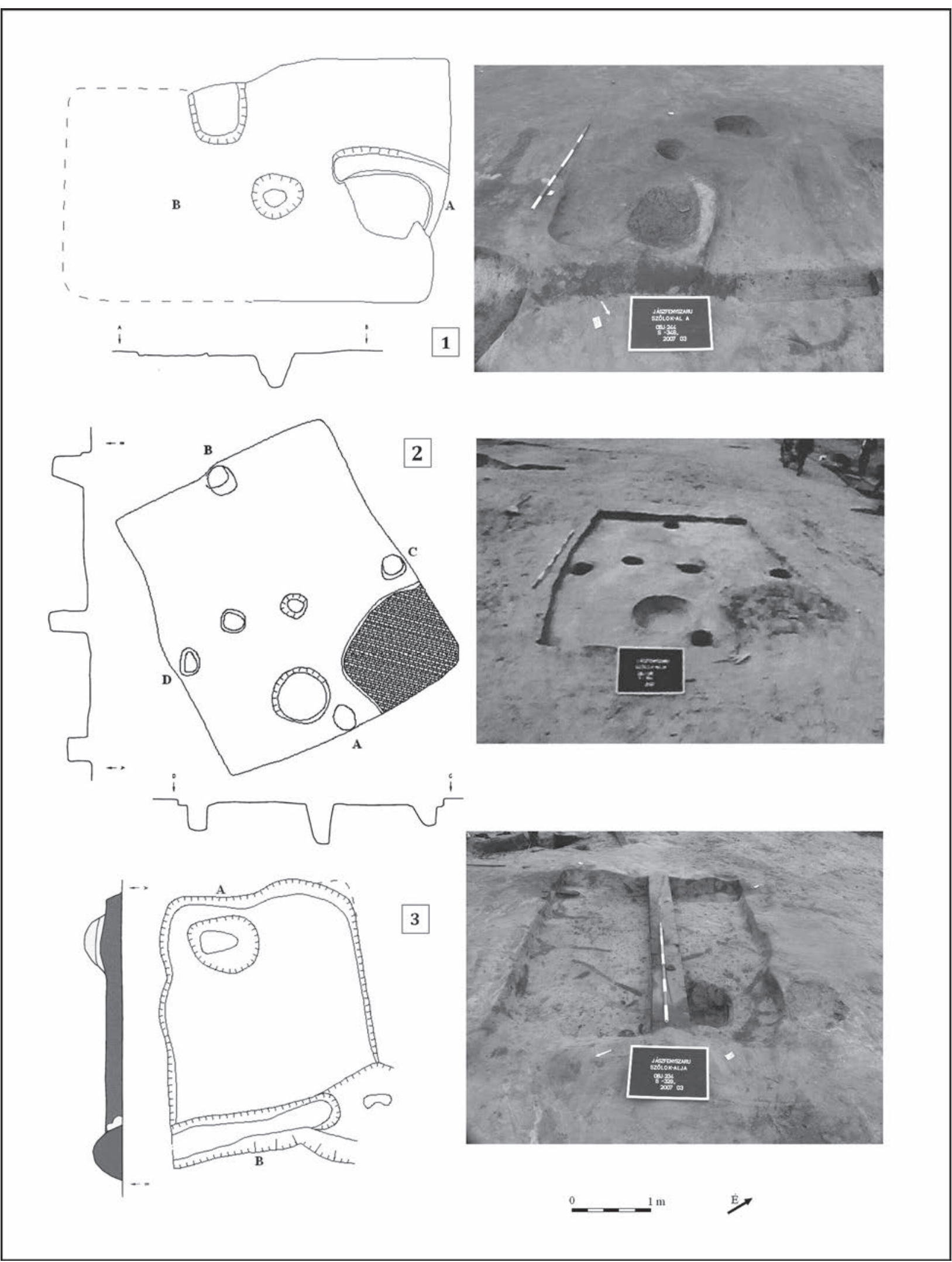

5. kép. Jászfényszaru-Szőlők alja. 1: Egy oszlop középen (9. ház); 2: négy oszlop az oldalak közepén és egy középen (36. ház); 3: oszlop nélküli ház (12. ház)

Fig. 5. Jászfényszaru-Szőlők alja. 1: A post in the middle (House 9); 2: four posts along the sides and one in the middle (House 36); 3: house without posts (House 12) 
Lébény-Bille-domb lelóhelyról. ${ }^{23} \mathrm{Az}$ oldalak mentén és középen elhelyezkedő tartóelemek valószínúleg felmenő falakra utalnak, amelyek koszorúgerendát tartottak, arra pedig sátortetó támaszkodott. A 12. században több lelőhely esetében is megfigyelhetó egy új fal- és tetóépítési eljárás, amely tényleges technológiai-szerkezeti változást hoz. Ennek során „felemelik” a tetőt. ${ }^{24}$ Ez a háztípus a település életének későbbi szakaszában jelenik meg: a 30. ház a település átmeneti, a 36. ház pedig a kései periódusához köthető. A falak mentén elhelyezkedő oszlopok kapcsán néhány lelőhelyen felmerült a házgödör fával (deszkával) való kibélelésének lehetősége, ${ }^{25}$ de Jászfényszarun nem került eló erre utaló nyom. Ehhez hasonló, de a középső oszlopot nélkülöző házat tártak fel Ménfőcsanak-Szeles-dúlőn, ${ }^{26}$ Lébény-Bille-dombon ${ }^{27}$ és Felsőzsolca-Várdombon. ${ }^{28}$

\section{Oszlop nélküli házak (12., 28., 29. ház) (5. kép 3)}

Három ház esetében egyetlen oszlophelyet sem találtak. Ezek az épületek tehát valamilyen felmenő falazattal rendelkeztek, amely nem igényelte külön oszlopok alkalmazását, és nem hagyott maradandó nyomot. Feltehetően fából készülhettek ezek a házak, de hogy milyen módon (pl. borona- vagy zsilipelt fallal), arra vonatkozóan nem rendelkezünk információval. A tető kialakítása szempontjából itt is nyereg- vagy sátortetővel számolhatunk. A 12. ház nem keltezhető pontosan, de az ezt vágó korai szabadtéri kemence alapján valószínúleg a település életének első fázisában állhatott, míg a 28. és 29. épületek már az átmeneti időszakot jelzik.

Egyéb szerkezetek (19., 21., 22., 24., 27., 42. ház)

Ebbe a csoportba kerültek azok az épületek, amelyek valószínúleg a fenti típusok „hiányos” vagy formai változatai, ugyanis csak egy-egy példány került elő belőlük. A 19. háznál az egyik rövidebb oldal sarkában és középen lehetett megfigyelni egy-egy oszlophelyet. Mivel a 18. épület a 19. ház nagyobb részét megsemmisítette (utóbbit az előbbi pótlására építhették), nem rekonstruálható, hogy pontosan milyen szerkezetú ez az épület. A 27. háznál - a 19. házhoz hasonlóan - az egyik rövidebb oldal sarkában és középen volt egy-egy

\footnotetext{
3 TAKÁCS 1996, 200; 211, 1. tábla 2; 213, 3. tábla 2.

4 RÁCZ 2014, 172.

25 ŠALKOVSKÝ 2011, 421.

26 TAKÁCS 1993, 29; TAKÁCs 2002, 279, Taf. 5, 4.

7 TAKÁCS 1993, 29.

8 SimONYI 2003, 114, 6. kép; 116, 9. kép.
}

oszlophely, azonban egy további tartóelem állhatott az egyik hosszanti oldal mentén, a sarokban lévő oszloppal nagyjából egy vonalban. Mivel itt is több objektum vágta az épületet, eredeti felépítését nem tudjuk pontosan rekonstruálni. Olyan szerkezeti elrendezést viszont ismerünk más lelőhelyekról, amely a ház közepén lévő egy, illetve a sarkaiban található négy másik oszlopból áll, és amelyet esetenként az oldalak közepén elhelyezett további tartóelemek egészítenek ki. Ugyanez a szerkezeti megoldás a középső oszlopok nélkül is előfordul például Ménfőcsanak-Szeles-dúlőn, ${ }^{29}$ Felsőzsolca-Várdombon, ${ }^{30}$ a szeri monostor területén, ${ }^{31}$ valamint Tatabányán. ${ }^{32}$

A 42. házban három oszlop kapott helyet: kettő a két rövidebb, a harmadik pedig az egyik hosszanti oldal közepén. Ez az épület valószínúleg a 30. és 36. házhoz hasonló szerkezettel rendelkezett. Meg kell említeni, hogy a 42. ház középső részétól kicsit északra egy $20 \mathrm{~cm}$ átmérőjü foltot figyeltek meg. A jelenséget a ház tetószerkezetének későbbi (utólagos) alátámasztásával magyarázták. Ez utóbbi feltételezés azonban nem igazolható, és statikai szempontból sem valószínú.

A 21. háznál egy oszlophely a rövidebb oldalon, egy pedig középtájt található, azonban nincsenek egy vonalban. A 22. épületben két oszlop állt egykoron, mindkettő az egyik hosszabbik oldal mentén, de nem közvetlenül mellette. A 24. házban több oszlophely is megfigyelhető volt, a szerkezeti elrendezést azonban az ásatáson tett megfigyelések alapján nem lehetett tisztázni. Az utóbbi három épület szerkezetét tehát nem lehet egyértelmúen rekonstruálni.

\section{Falazat}

Felmenő falazatra elsősorban a betöltésben talált tapasztásmaradvány és omladék alapján következtethetünk, ${ }^{33}$ de esetenként az egyes épületek szerkezeti elrendezése is sejteti ezek meglétét. A 44 közül csak 18 ház esetében van adatunk omladékos és paticsos betöltésről. Ezeknél sem mindig egyértelmú, hogy a ház falainak vagy kemencéjének maradványai kerültek-e a betöltésbe. Mindemellett számolni kell azzal a lehetőséggel is, hogy a falakat olyan anyagból, illetve olyan megoldással is készíthették, amely nem hagyott régészetileg dokumentálható nyomot.

\footnotetext{
29 TAKÁCS 1993, 29.

30 SimONYI 2003, 113, 4. kép.

31 VÁlyi 1986b, 225.

32 A tatabányai házról közölt rekonstrukció alapján itt is nyeregtető használatát feltételezhetjük (VÉKONY 1980, 29).

33 TAKÁCS 1993, 30.
} 
A két ágasfás épületek közül nyolcnál (1., 10., 11., 15., 20., 23., 31., 44. ház) lehetett megfigyelni paticsos, omladékos betöltést, amely esetleg utalhat az egykori felmenő falak meglétére. A három ágasfás házak közül csak három (16., 38., 40. ház) betöltése tartalmazott omladékot és paticsot. Azon házak között, amelyek csak az egyik oldalon rendelkeztek egy vagy két oszloppal, három épület (5., 7., 8. ház) betöltése volt paticsos, omla-
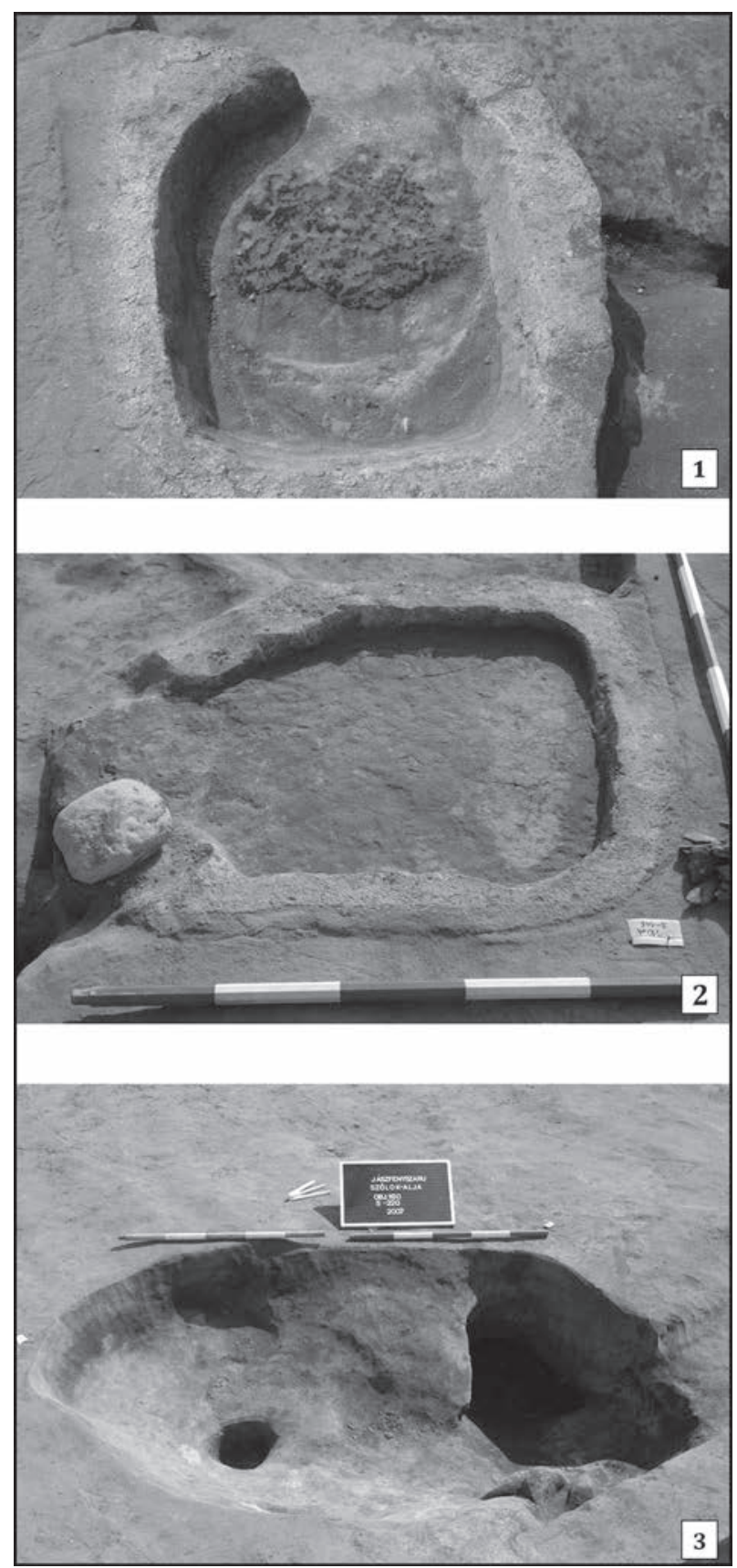

6. kép. Jászfényszaru-Szőlők alja. 1-2: Vájt és tapasztott kemencék (34. és 20. ház); 3: szabadtéri kemence (3. kültéri kemence)

Fig. 6. Jászfényszaru-Szőlők alja. 1-2: Sunken and plastered ovens (Houses 34 and 20); 3: open-air oven (open-air oven 3) dékos. A nem rekonstruálható szerkezetú házak közül csak a 21. épület betöltésében találtak paticsot. A 30., 36. és 42 . házak esetében az oldalak mentén, valamint a 19. és 27. épületnél a sarkokban elhelyezett oszlopok miatt már mindenképpen számolnunk kell a felmenő falak meglétének lehetőségével, annak ellenére, hogy az ásatás során nem minden esetben (csak a 42. háznál) jelezte az egykori falak meglétét a betöltésből előkerülő tapasztásmaradvány. Ez viszont arra hívja fel a figyelmünket, hogy biztosan voltak olyan felmenó falú épületek (is) a település házai között, amelyek nem betapasztott vesszőfonatos falazattal rendelkeztek, hanem fából készültek. A korábbi feltételezésekkel ellentétben a fa megfizethető és elérhető volt az Árpád-kori közember számára, ${ }^{34}$ így egészen valószínú, hogy némelyik házat fából építették.

\section{Bejárat}

Az Árpád-kori épületek bejáratát csak ritkán és nehezen lehet megfigyelni. Ezek többnyire meneteles vagy lépcsős kiképzésúek. ${ }^{35}$ Jászfényszarun a 44 épületből mindössze 7 háznál (10., 11., 12., 13., 15., 16., 33. ház) lehetett többé-kevésbé beazonosítani a bejárat helyét. A bejárati rész minden esetben meneteles kialakítású volt, helye azonban változatos képet mutat még ennél a hét háznál is. Négy épületnél a délnyugati, kettőnél az északnyugati, illetve egynél a délkeleti sarokban alakították ki a meneteles bejáratot. Az Árpád-kori házak többségénél a kemencével átellenes sarokban tételezték fel a bejárati rész meglétét. ${ }^{36}$ Jászfényszarun a 10., 15. és 33. ház esetében a kemencével átellenes sarokban kapott helyet a bejárat, a 11., 12., 13. és 16. házban pedig a kemencéhez képest az egyik szomszédos sarokban. A Szőlők alján megfigyelhető bejáratok száma csekély, a hozzájuk tartozó épületek pedig felölelik a település korai, átmeneti és kései periódusát is, így nem állapíthatók meg egy-egy időszakra jellemző tendenciák.

\section{Padló}

A jászfényszarui épületekben nem lehetett megfigyelni döngölt, letaposott padlót. A legtöbb ház alja egyenes volt - kivéve a bolygatott épületeket -, de szándékosan kialakított padlószintet nem találtak. Nem kizárt, hogy valamilyen anyaggal

\footnotetext{
34 Wolf 2014, 24.

35 MiChNAI 1981, 227; TAKÁCS 1993, 31; TAKÁCS 1996, 202.

36 TAKÁCs 1993, 31; BENCZE 1999, 21.
} 
(fával, gyékénnyel vagy egyéb szerves anyaggal) letakarták a házak padlóját, hiszen más lelóhelyekről ismerünk ilyen megoldásokat, ${ }^{37}$ de erre utaló nyomok itt nem kerültek elő.

\section{A házak tüzelőberendezései}

Minden ház rendelkezett tüzelóberendezéssel, amelynek sütőfelülete, illetve omladékai legalább részben megmaradtak, vagy égett folt jelezte egykori meglétét. Egyedül a 40. ház esetében van adatunk túzhelyről, amelynek $\mathrm{kb} .30 \mathrm{~cm}$ átmérőjú maradványát találták meg. A tüzelőberendezés töredékes állapota miatt az sem kizárható, hogy eredetileg itt is kemence állt, ugyanis az összes többi ház rendelkezett kemencével. A 2., 3., 15., 36. és 43. épületeknél csak az egykori kemencék nyomait lehetett megfigyelni, de a legtöbb háznál viszonylag jó állapotban maradt meg a kemence alsó része. A legtöbb esetben (28) a ház északkeleti sarkában alakították ki, több alkalommal azonban az északi (5), az északnyugati (4), illetve ritkábban a keleti (2), a délkeleti (2) és a délnyugati (2) sarokban is megfigyelhetók voltak a kemencék. A 24. ház esetében nincsen adatunk a kemence pontos helyére vonatkozóan.

Ahol megfigyelhetó volt a tüzelöberendezés építési technikája, ott minden esetben tapasztással, illetve részben vájással készültek a szögletes vagy kerekded, ovális formájú, agyagból épített kemencék. Ezeket többnyire úgy alakították ki, hogy egyik oldalukat és hátsó falukat a ház két oldala biztosította, így már csak a nyílásuk és a másik oldaluk felóli falat kellett teljesen megépíteni (6. kép 1-2). Az agyagkemencék általános jellemzői a 11-12. század fordulója és a 14. század közepe közötti időszak épületeinek. ${ }^{38}$ A kemencék eredeti alakját nem minden esetben lehet meghatározni, de ahol erre lehetőség nyílt, ott a kívül négyszögletes, belül kerekded vagy ovális formájú kemencék dominálnak, míg a kívül-belül kerek vagy ovális formát mutató példányok csak öt házban fordultak elő (11., 15., 17., 32., 42. ház). Majdnem minden kemence rendelkezett szépen kialakított tapasztott sütőfelülettel, de a 7., 21., 23., 33. és 36. házak kemencéinél ezt már nem lehetett megfigyelni. A 7., 32. és 33. háznál a sütőfelület alatt köveket helyeztek el, majd erre építették fel a tapasztott részeket. Ezek a kemencék nem alkottak kronológiailag elhatárolható csoportot a többi tüzelőberendezéshez képest, ugyanis az említett három ház leletanyaga alap-

\footnotetext{
37 VÁLYI 1986b, 234.

38 TAKÁCS 1993, 21; TAKÁCS 2002, 282.
}

ján mind egy-egy külön periódust képviselt (korai, átmeneti és kései fázis). A 33. ház esetében őrlőkő-töredékeket használtak a sütőfelület hőtartásának növelésére, míg a 44 . ház kemencéjének sütőfelületébe kerámiákat tapasztottak. A 20. ház kemencéjének nyílásánál, a tapasztás végén egy nagyméretú kő került elő (6. kép 2), míg a 23. épület kemencéjében egy őrlőkő-töredéket találtak. A 42. ház kemencéje előtt egy kisebb cölöphelyet tártak fel, amely szikrafogó meglétére utalhat. ${ }^{39}$ A kemencék felénél lehetett meghatározni a nyílás irányát, amely a legtöbb esetben (11) a déli, gyakran a keleti (7), ritkábban (4) a délnyugati részen volt megfigyelhető. A kisalföldi Árpád-kori házakban tapasztaltakhoz hasonlóan ${ }^{40}$ az esetek többségében itt is a ház kemencével szemközti, hosszabb oldala felé nézett a nyílás. Több épületben előfordultak különböző méretú hamusgödrök, bár a gödrök másodlagosan is megtöltődhettek hamuval. Ezek egy része akár későbbi tevékenységre is utalhat, ugyanis több korábbi épület gödrében (10., 13., 31., 34., 35. ház) szabadtéri kemencét alakítottak ki.

\section{Berendezési elemek}

Az Árpád-kori házak berendezési elemeinek nyomait csak különösen szerencsés esetekben figyelhetjük meg, ${ }^{41}$ mivel a Kárpát-medencei éghajlat nem kedvez a fából vagy egyéb elbomló anyagból készített alkalmatosságoknak. Egyértelmúen berendezési tárgyra utaló maradvány Szőlők alján sem került elő, azonban az épületek elemzése során feltünt, hogy több épületben is (17., 18., 24., 44. ház) megfigyelhető volt két-két nagyobb kerek, olykor enyhén négyszögletesedő gödör, amelyek a ház egyik - többnyire hosszabbik - oldalával párhuzamosan, egy vonalban helyezkedtek el. A gödrök mérete és mélysége páronként - de akár az egyes házakat összevetve is - hasonló volt. Átmérójük $50-75 \mathrm{~cm}$, mélységük $20-35 \mathrm{~cm}$ között változott. Ezekhez hasonló méretú és elhelyezkedésú gödröket lehetett megfigyelni Tiszaeszlár-Bashalmon a 12. házban. ${ }^{42}$ A gödrök sekély voltuk miatt tárolásra kevéssé voltak alkalmasak, illetve ebből eredően munka- vagy ülőgödörként sem voltak előnyösek. A szakirodalomban többnyire ülö- vagy munkagödörként aposztrofált, házon belül elhelyezkedő objektumok kapcsán

\footnotetext{
39 Wolf 2001, 133-134; Wolf 2002, 45.

40 TAKÁCS 1993, 19.

41 Ilyen kedvező esetként említhető például a borsodi 8. ház (WoLf 2002, 45), illetve a Cegléd határában feltárt, a tatárjárás során elpusztult és leégett 1344. sz. épület (GULYÁs 2014, 31, 33).

42 KovalovszKi 1980, 34-35, 23. rajz.
} 
Rácz Tibor Ákos jegyezte meg, hogy ezek több veszélyforrást és plusz munkát jelentettek a házon belül, mint amennyi kényelmet nyújtottak. Felvetette, hogy sokkal praktikusabb lett volna egy fatuskót vagy követ alkalmazni ülőalkalmatosságként. ${ }^{43}$ Észrevétele logikus és elfogadható, így a jászfényszarui épületekben megfigyelhető, a ház hosszanti oldala mentén, egy vonalban elhelyezkedő, azonos méretú, sekély gödrök kapcsán megfogalmazódott bennem a gondolat, miszerint ezekbe esetleg nagyobb fatuskót helyezhettek. A 20-35 cm mélységú gödör lehetővé tette, hogy stabilan beleállítsanak egy fatuskót, amely önmagában ülőalkalmatosságként funkcionálhatott, illetve a két szemközti tuskó és egy vagy több falap (deszka) együttes használatával egy tárolásra, munkára vagy éppen fekvőhelynek is alkalmas felületet hozhattak létre. Ez egyelőre természetesen csak hipotézis, mivel maguknak a feltételezett faelemeknek a nyoma nem maradt meg. Az említett gödrök elhelyezkedése azonban semmiképpen sem tekinthető véletlenszerúnek.

A fentiek alapján jól látható, hogy az Árpád-kor sokkal változatosabb képet mutat az épületek tekintetében, mint ahogyan azt a kutatás sokáig feltételezte. ${ }^{44} \mathrm{~A}$ már jól ismert, de korántsem kizárólagosan jelen lévő, ágasfás-szelemenes szerkezetú, változó mértékig földbe mélyített házak mellett - amelyek sokszor önmagukban is nagy formai változatosságot mutatnak, akár egy-egy kulturális és földrajzi egységen belül is ${ }^{45}$ - több szerkezeti forma is megfigyelhetó. ${ }^{46} \mathrm{Az}$ egyes háztípusok a jászfényszarui (és több más Árpádkori) lelőhely esetében nem rajzolnak ki egy egyértelmúen levezethető fejlődési sort. Gyakran egy időben vannak jelen, illetve némelyik házforma akár több évszázadon keresztül is használatban lehetett. A szerkezetük alapján felmenő fallal rendelkező épületek, amelyeknek a betöltése nem tartalmazott tapasztott sövényfalra utaló maradványokat, fából épülhettek. Ugyanígy földfelszíni házakat is építettek fából - zsilipelt, boronafalas vagy egyéb megoldással. ${ }^{47}$ Földfelszíni épületekkel a 10. századtól kezdve számolhatunk. Ezek többsége nem a társadalom kiváltságos tagjainak szolgált lakhelyül, ${ }^{48}$ tehát semmi nem zárja ki esetleges jászfényszarui

\footnotetext{
43 RÁCZ 2014, 168.

44 Az Árpád-kori népi építészettel kapcsolatban Wolf Mária sorakoztat újabb fontos adatokat: WOLF 2014.

45 TAKÁCS 1993, 32; TAKÁCS 1996, 199-201; ŠALKOVSKÝ 2011, 420

46 RÁCZ 2014, 145.

47 Wolf 2014, 30

48 WOLF 2014, 37
}

jelenlétüket. Nyomaikat azonban - ha voltak - a gépi humuszolás eltüntette.

A Szőlők alján megfigyelt különböző épülettípusoknál néhány szerkezeti elem többnyire hasonlóságot mutat. Így általánosságban elmondható, hogy a lakók a meneteles kialakítású bejáraton keresztül jutottak be a házba. A bejáratokkal átlósan szemben vagy az egyik szomszédos sarokban kapott helyet a vájt-tapasztott kemence, amelynek szintén tapasztott sütőfelületét ritkábban kővel vagy kerámiával rakták ki. Az épületben kiásott, különböző mélységú gödrök a bent végezhető munkák megkönnyítésére, de akár tárolásra is szolgálhattak. A házak kialakítását, belső elrendezését tekintve jó párhuzamként említhető a Méri István által feltárt tiszalök-rázomi Árpádkori település, ugyanis mind a házak formája, mind a kemencék és az oszlophelyek elhelyezkedése sok hasonlóságot mutat. ${ }^{49} \mathrm{~A}$ házak tájolása, a kemencék helye, kialakítása, formája, még a házgödrök mérete is szinte teljesen azonos, fóként a két ágasfás házak esetében. Hasonló képet mutatnak a Kárpát-medencéből ismert kora középkori épülettípusok ${ }^{50}$ és a Szigetszentmiklós-Üdülósoron feltárt épületek is. ${ }^{51}$ Számos további, hasonló jellegú Árpád-kori települést lehetne párhuzamként megemlíteni: többek között a házainak egyik csoportjával szintén hasonló sémát mutató Kána falut, ${ }^{52}$ Ménfő́csanak-Szeles-dúlót, LébényBille-dombot, ${ }^{53}$ Orosháza-Nyíri-dúlőt ${ }^{54}$ vagy az M0-ás autópálya és a 4-es számú elkerülő fóút nyomvonalán feltárt teleprészleteket. ${ }^{55}$

\section{Településszerkezet}

\section{A falu térbeli elhelyezkedése a felszinmodell tükrében}

A térinformatikai módszerek egyre nagyobb szerepet kapnak a régészeti munkálatok során. ${ }^{56}$ Egy-egy program segítségével összetett feladatokat lehet viszonylag egyszerúen és gyorsan elvégezni, ezáltal pedig olyan információkhoz juthatunk, amelyek ezen alkalmazások használata nélkül talán elkerülnék a figyelmünket. ${ }^{57}$

A Szőlők alján 2007-ben végzett feltárás során bemért pontok közel tízezres adatbázist képez-

\footnotetext{
49 MÉRI 1952, 58-59.

50 ŠALKOVSKÝ 2001; ŠALKOVSKÝ 2011.

51 ÍRÁSNÉ Melis 1992, 62, 4. kép; 63, 5. kép.

52 TEREI 2010a, 249; TeREI 2010b, 88, 92, 89, 7. ábra.

53 TAKÁCS 1996.

54 LUKÁCS 2014, 108.

55 RÁcZ 2010; RÁcZ 2014.

56 Árpád-kori településkutatásban pl. RINGER-SzÖRÉNYI 2011.

57 RINGER-SZÖRÉNYI 2011, 512.
} 
nek. ${ }^{58}$ Ennek segítségével viszonylag pontos felszínmodellt lehetett készíteni, amelyen jól láthatók a terület egyes részei közti szintkülönbségek (3. kép). ${ }^{59}$ Az egyes objektumok könnyebb beazonosítása érdekében a kész domborzatmodellre illesztettük a feltárás felszínrajzát (1. kép). Ahogyan az sok esetben megfigyelhetó, ${ }^{60} \mathrm{itt}$ is a víz közelében telepedtek le az emberek, egy homokdomb hátára. A Zagyva és kisebb ágai ma is ott kanyarognak Jászfényszarunál, de korábban voltak vízjárta, szinte lápos területek. Az első katonai felmérés térképén még megfigyelhetők a Szőlők aljától északra elterülő vizes sávok (7. kép 1), amelyeket összefoglaló néven "Só mocsárként” jelöltek a második és a harmadik katonai felmérés térképein (7. kép 2-3). Ebből a környezetből emelkedett ki 2,7 méteres szintkülönbséggel az Árpád-korban is lakott homokhát. A felszínmodellen egyértelmúen kirajzolódnak a világosabb árnyalattal jelölt magasabb részek, ahol az objektumok többsége található. A legmagasabb részeken figyelhetó meg a telepjelenségek súrübb csoportja.

Hogy Szőlők alján mennyire kapott hangsúlyt a magasság és az egybefüggő településstruktúra, az jól látható a képen, a település északi objektumcsoportjánál (3. kép). Amennyire lehetett, kihagyták a két magasabb rész között húzódó alacsonyabb sávot, és a következő gödröket, árkokat már a magasabban fekvő térszínen alakították ki.

Házsorok és utca a jászfényszarui Árpád-kori faluban

A Szőlők alján végzett megelőző ásatásig, illetve az így nyert eredmények feldolgozásáig nem volt egyértelmú, hogy pontosan milyen jellegú település állt itt egykor. A tárgyalt lelőhelyet Selmeczi László korábban „csupán egy tanyaszerü gazdasági egység nyomaiként" írta le. Véleményét érthetó módon - a dolgozat elején már említett, szomszédos Árpád-kori lelőhelyek közelségére alapozta. ${ }^{61} \mathrm{Az}$ ismertetett falurészlet kiterjedése alapján azonban érzékelhetô, hogy egy viszonylag nagy területú, hosszú életú Ârpád-kori falu nyomait sikerült feltárni. Tehát elvethetjük, hogy ez csupán egy kisméretú, jelentéktelen, ad hoc módon létrejött gazdasági egység lett volna. Bár a 44 épület nem egy időben állt, periódusonként

58 Az adatbázist az Archeodata 1998 Bt. készítette, és a Damjanich János Múzeum engedélyével került felhasználásra.

59 A felszínmodell létrehozásában dr. Mucsi László és Tobak Zalán voltak segítségemre. Munkájukat ezúton is köszönöm.

60 Többek között Pácin-Alharaszton (RINGER-SZÖRÉNYI 2011, 503).

61 SELMECZI 2011, 37. is legalább tíz-tizenöt házzal számolhatunk a megismert településrészleten. A falu feltáratlan részének kiterjedése egyelőre ismeretlen, így nem tudhatjuk, hogy még hány további ház állhatott a település egyes periódusaiban.

A jászfényszarui település szerkezetét tekintve szembetúnó, hogy az objektumok többsége egy északnyugat-délkeleti sávban található, amely a felszínmodell alapján egybeesik a legmagasabban húzódó területtel (3. kép). ${ }^{62}$ Az egyes házak elhelyezkedése sem esetleges, hanem sok esetben kifejezetten rendezett képet mutat. A korai épületek többsége nagyjából egy északnyugat-délkeleti vonalba rendeződve követi a magasabb rész déli ívét (26., 23., 5., 6., 8., 3. ház), egy részük pedig ettől a vonaltól néhány méterrel délebbre (22., 21., 17., 20., 19., 18., 4., 1., 9., 2., 3. ház), illetve a településrészlet északkeleti részén található (32., 31. ház). Az északnyugat-délkeleti házsorra merőlegesen a szelvény nyugati széle mentén egy másik házsor is kirajzolódik (22., 26., 29., 27., 30. ház), amelynek északi épületei már az átmeneti időszakra tehetők. Ennek az időintervallumnak a többi háza a települési centrum délnyugati (15., 17. ház) és északkeleti részein állt (39., 38., 33., 37. ház). A kései periódus lakóépületei aránylag jól illeszkednek a korábbi házak által „előrajzolt" északnyugat-délkeleti házsorba (24., 25., 7., 11. ház), illetve újabb házsorokat alkotnak ezzel párhuzamosan (44., 42. ház) valamint merőlegesen (42., 43., 45. ház) a falu északkeleti részén. Erre az időszakra keltezhetó a 36. ház is, amely az előbbiektől valamivel keletebbre található a korábbi időszakokban is lakott területen.

Az előbbiek alapján egyértelmúen kirajzolódik egy nagyjából északnyugat-délkeleti irányú sáv, amelynek szélessége 17 és 33 méter között változik. Itt tehát egy beépítetlen, házsorok által szegélyezett utca meglétével számolhatunk. ${ }^{63} \mathrm{Az}$ utca létezését az is alátámasztani látszik, hogy az érintett területen az eddigi eredmények alapján nem található az épületekkel azonos korú objektum, tehát egy üres sávról van szó. A fentiek alapján az utca déli és északi oldalát képező házak nem mind álltak egy időben, soros elhelyezkedésük az érintett sáv mentén mégis kirajzolja az utca vonalát. Ez szintén azt támasztja alá, hogy ezen a részen egy a kora Árpád-korban kialakított és több generáción át létező utcasáv húzódott, amely fontos szempont volt a későbbi házak építési helyének megválasztásában is. Itt

62 Gyakorlatilag ugyanezt a magas térszíni elrendeződést tapasztalhatjuk Pácin-Alharaszton (RINGER-SzÖRÉNYI 2011, 511).

63 BíRÓ 2013a, 147, 157; BíRÓ 2013b, 9, 33-35; BíRÓ 2014, 115. 
tehát a régészeti és a térinformatikai módszerek együttes alkalmazása világított rá, hogy már a település korai periódusában feltételezhetó egy utca (zsákutca?) megléte. A házak - a falu életének több periódusán át - ehhez igazítva helyezkedtek el, és az egyes családoknak valószínúleg megvolt az állandó területük (portájuk?), ahol építkezhettek. Rögzített telekhatárokra következtethetünk bizonyos házak megújításából is. A 17. házat a 16., a 19. házat a 18., míg a 27. épületet a 29. váltotta. Ezek a lakóházak a korábbiak helyén épültek fel, ami némi terep-elókészítést igényelt. Ha „szabad” lett volna a mozgás a településen belül, ugyan miért szántak volna időt és energiát arra, hogy a korábbi területet beépíthetơvé tegyék, ahelyett, hogy néhány méterrel arrébb húzták volna fel az új házat?

A rendezett településstruktúráról árulkodó adatok azért fontosak, mert az így létrejött falukép, településszerkezet jelen esetben nem igazolja a Méri István nyomán ${ }^{64}$ meghonosodott, azóta többek által általánosan és kizárólagosan elfogadott településképet, amely szerint a kora Árpádkori települések laza szerkezetúek, szórtak voltak, és házaik egymástól távol, rendszertelenül helyezkedtek el. Az utca nyugati folytatása kérdéses, a feltárt objektumok elhelyezkedése alapján azonban valószínú, hogy keleti irányban továbbhaladt. A korábbi térképeket, így az első és második katonai felmérést, valamint id. Bedekovich Lőrinc alkotását tanulmányozva feltúnik egy út - Bedekovich térképén ez Hatvanyi út néven szerepel -, amely északkelet-délnyugati vonalban halad Szőlók alja déli, délkeleti határai mentén (7. kép 1-2, 4). Bár az említett három térkép 18-19. századi viszonyokat tükröz, nem kizárt, hogy korábban is futott itt valamilyen út, amelyre az Árpád-kori falulakók északnyugatdélkeleti irányú utcájukon körülbelül 500 métert kelet felé haladva éppen kijuthattak.

A kutatás jelenleg három Árpád-kori falutípust különít el: a Méri-féle szórt települést, a tanyaszerú településeket és a szabályos elrendezésú, utcás falvakat. ${ }^{65} \mathrm{Az}$ elóbbiek alapján ez a település nem sorolható a Méri-féle szórt települések közé, ugyanakkor a házak száma és egymáshoz való közeli elhelyezkedése miatt tanya- vagy szállásszerúként sem lehet leírni. Teljesen szabályos elrendezésről ugyan nem beszélhetünk, de a kimutatható utca és a házsorok alapján a kutatás jelenlegi fázisában a rendezett, utcás falvak közé lehet sorolni.

\footnotetext{
4 MÉRI 1952.

65 TAKÁCS 2010, 14-18.
}

Egyes Árpád-kori falvaknál tapasztalható, rendezett településszerkezetról nem csak a mostani eredmények, hanem más Árpád-kori településeken végzett feltárások, illetve a történeti források is tanúskodnak. A területi osztás csírái nem csupán a korszak végén, hanem már 10-11. századi településeken is megfigyelhetők - jó példa erre Ménfőcsanak-Szeles-dúlő. ${ }^{66}$ Kiskunfélegyháza-Amler-bányán különböző típusú, félig földbe mélyített Ârpád-kori épületeket tártak fel, amelyek többsége egy északkelet-délnyugati irányú, utcás rendbe illeszkedett. A házak két sort alkottak, és ettől a két házsortól délre helyezkedett el további két épület. A két csoport közötti viszony nem volt megállapítható, mert a köztük lévő területet elpusztították a földkitermelés során. ${ }^{67}$ Házsoros és utcás elrendezés főként késő Árpád-kori telepfeltárásokon volt megfigyelhető. Többek között Dunaújvárosból ismertek házsorok, ${ }^{68}$ valamint Veresegyház-Ivacson véltek felfedezni ilyen módon rendezett épületeket. ${ }^{69} \mathrm{Az}$ utóbbi lelőhely esetében Takács Miklós szerint nem beszélhetünk egykorú házsorról, mivel egyes házakat egymásba ástak. ${ }^{70} \mathrm{Ez}$ a jelenség azonban arra is utalhat, hogy - mint azt a jászfényszarui házaknál is láthattuk - a korábbi ház helyén építették fel az új épületet. Tehát az újabb házak kialakításakor az utcához igazodtak, illetve figyelembe vették a már kialakult települési rendet. Szintén házsorokat tártak fel KecskemétKiscsukás 44/II/2. lelőhelyen. 40-50 méter hoszszan alkottak házsort a Cegléd-Madarászhalmon talált épületek. ${ }^{71}$ Szeren is sikerült feltárni két, egymással L alakban érintkező, sorba rendeződött négy-négy nagyobb, bonyolultabb szerkezetú épületet, amelyeket a 11. század közepe és a 12. század közepe közé lehetett keltezni. ${ }^{72}$ Út, utca meglétére is több adattal rendelkezünk. Így többek között a Tiszafüred-Morotvaparton feltárt falut egy út osztotta ketté. ${ }^{73}$ Három házsor került elő Szigetszentmiklós-Üdülósoron, ${ }^{74}$ illetve derékszögben megtörő házsort figyeltek meg Lébény-Bille-dombon. ${ }^{75}$ Északnyugat-délkeleti irányú, 8 méter széles, 130 méter hosszú utcát, valamint abból délkeleti irányban leágazó három

\footnotetext{
66 TAKÁCS 1993, 40; TAKÁCS 1996, 207.

67 Gallina-MolnÁr 2004, 537; GallinA-GulyÁs-MolnÁR 2014, 321.

68 BÓNA 1973, 80.

69 MESTERHÁZY 1983, 147.

70 TAKÁCS 2010, 14.

71 GULYÁs 2007, 52.

72 VÁlyi 1986a, 123

73 LASZLOVSZKY 1991, 351.

74 IRÁSNÉ MELIS 1992, 41.

75 TAKÁCs 1996, 216, 6. tábla; ugyanez a rajz: TAKÁCs 2010, 19, 11. ábra.
} 

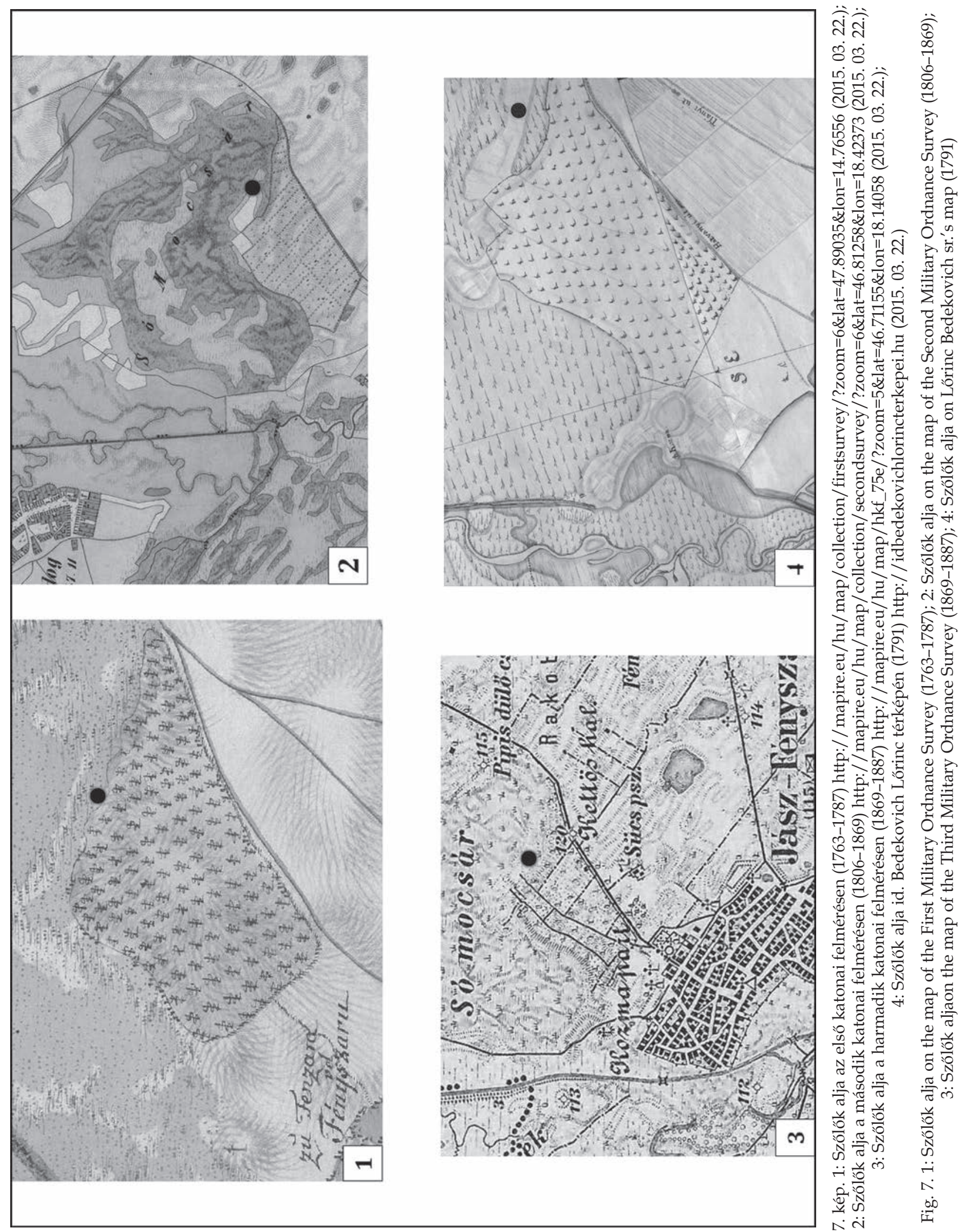
mellékutcát tártak fel Rákospalota-Újmajor lelöhelyen. A főutca két oldalán szabályos telekosztást tudtak megfigyelni. A falu használati ideje a 12. század második fele és a 13. század első fele közötti időintervallumra tehető. ${ }^{76}$

A rendezett szerkezetú, soros-utcás falu legkorábbi nyomai már a honfoglalás előtti településállományban is megfigyelhetók. Ennek a településtípusnak a kifejlódése és elterjedése a megszilárduló feudalizmussal, a jobbágytelek-rendszer kialakulásával kapcsolható össze. Az utca vonala nem mindig tekinthetó szabályosnak, mivel alkalmazkodik a domborzati és egyéb természeti adottságokhoz, továbbá a fontosabb épületekhez (vár, templom) is igazíthatták. Az oklevelek különlegesebb utcákról, így körkörösen, kerek sorban vagy körben elhelyezkedő utcákról is beszámolnak. ${ }^{77}$ A szabályos alaprajzú falvaknál mindig fontos szerepet játszott az utca, amelynek irányához az épületeket igazíthatták. Az utca szó oklevelekben előforduló latin formái (platea, contrata, vicus, linea, ordo, via) utalhatnak az adott település formájára. A 14-15. századi települések gyakran csak egy utcával rendelkeztek, de már korán megjelentek a többutcás falvak is. A jász és a kun szállásokon szintén hoztak létre utcákat a 14. század folyamán. Az Árpád-házi királyok kora után Károly Róbert idejében általánosnak tekinthetők az utcás falvak. Ezt a király által kivetett "kamara haszna" adónem is jól mutatja, a király 1336-os oklevele szerint ezt az adót ugyanis az utcára nyíló kapuk után vetették ki. ${ }^{78}$

\section{Árkok és egyéb objektumok}

Az egyéb objektumok további vizsgálatot igényelnek, így most csak a településszerkezet szempontjából különös fontosságú telepjelenségeket, elsósorban az árkokat, karámokat, illetve a házak közelében található vermeket és kültéri kemencéket mutatom be röviden. Az egyéb objektumok kapcsán fontos megemlíteni, hogy egyetlen kút sem látott napvilágot az ásatás során, sem az Árpád-kor, sem pedig a korábbi korok idejéből. ${ }^{79}$ Ennek fényében vagy a környezetben fellelhetó természetes vizek biztosították

\footnotetext{
76 BENCZE 1999, 23-24.

MAKSAY 1971, 91-110.

SZABÓ 1969, 132-140.

79 Sem Ménfőcsanak-Szeles-dúlőn, sem Lébény-Bille-dombon nem akadtak a 10-11. század fordulója elé keltezhető, így a településekhez köthető kutak nyomára, habár utóbbi lelőhelyen későbbi kutakat sikerült feltárni. A korábbi települések lakóit valószínúleg a közeli természetes vízfolyások látták el (TAKÁCS 1996, 199).
}

a vízszükségletet, vagy a faluhoz tartozó kút/ kutak a még feltáratlan területeken helyezkednek el.

\section{Árkok}

Az árkok Árpád-kori falvaink gyakori objektumai. Különböző funkciójukat illetően Méri István munkáját vehetjük alapul. ${ }^{80}$ A teleprészleten viszonylag nagy számban előforduló árkok és árokrendszerek a szuperpozíciók alapján néhány esetben korábbinak, illetve az esetek többségében későbbinek mutatkoztak az Árpád-kori épületeknél. Csak egy ároknál (O-68S-82) valószínúsíthetó, hogy egykorú a környező házakkal, illetve leletanyaga alapján még a településrészlet déli szélén húzódó kettős árokrendszer létezhetett ezzel egy időben. Nehézséget okoz, hogy több olyan árok is található a házak közvetlen környezetében, amelyek szuperpozíció és/vagy lelet híján nem nyújtanak biztos keltezést (pl. O-245 S-348, O-163 S-223 stb.). Ugyanakkor némely árkoknál (pl. O-190 S-262) éppen a túl sok szuperpozíció, illetve a kevert leletanyag miatt problémás a relatív időrend felállítása. Ezért úgy vélem, érdemes a kronológiát elsősorban a szuperpozíciókra, nem pedig az árkokban talált leletekre alapozni.

A településszerkezet szempontjából a 4 . és az 1. ház között húzódó O-68 S-82-es árkot fontos megemlíteni (1. kép). Ez a 20-21 cm relatív mélységú, $30 \mathrm{~cm}$ széles árok meredek oldalfalaival, teknős aljával a dokumentációban vízelvezetó árokként szerepelt. A feltételezés elfogadhatónak túnik annak fényében, hogy az árok éppen merőleges a dombhátra, így nagyobb zivatar idején ennek segítségével elvezethették a lejtőn lezúduló esővizet a két ház között. Az árok a házaktól 2-2 méter távolságra, a házoldalakkal párhuzamosan helyezkedik el, így telekhatár szerepét is betölthette. Az eredeti járószintet nem ismerjük, ezért az árok teljes mélységét és a felszínen mérhetó szélességét nem lehet meghatározni. Nem dönthető el biztosan a funkció kérdése sem. Portakerítésre utaló árkok, árokrendszerek több lelőhelyről ismertek. ${ }^{81}$

A korai időszakra tehetó leletanyaggal rendelkezett az O-1 S-1 árok. Az O-1-es árokhoz viszo-
80 MÉRI 1962.

81 Többek között Hejőkeresztúron (Wolf 1999, 166-167) és Rákospalota-Újmajor lelőhelyen (BENCZE 1999, 23-24) sikerült feltárni tisztán kirajzolódó, portakerítésként értelmezhető árokrendszereket. 
nyított helyzete alapján feltehetóen ennek az árokrendszernek a másik vonalát alkothatta az O-3 S-3, 4, 5 és az O-2 S-2 árok is. Ezek talán már a település déli határát jelölik. A sok árok között leginkább az O-175 S-239 és O-174 S-238 árok, illetve az előbbi egyes ágai keltezhetők. Ez az árokrendszer ugyanis olyan épületeket vágott, amelyek leletanyaguk alapján biztosan a késő Árpád-korra keltezhetők (7. és 44. ház). Ehhez az árokhoz tartozhatott nyugat felól az O-60 S-88 árok, amelynek nyugat felé nyúló ága az O-41 S-51-es árok. Az O-175 S-239-cel párhuzamosan fut az O-45 S-55, O-89 S-111 és S-123 alkotta árok, amely iránya alapján feltehetóen az O-169 S-235ös árokban folytatódik. A településrészlet nyugati szélén az O-117 S-158 és S-157, illetve ennek folytatása, az O-63 S-76 árok egy hosszú, északkelet-délnyugat irányú árkot alkot, amely a 22. és 26. korai, illetve a 27. és 30. átmeneti periódusból származó házakat vágja. Ezek tehát minden bizonnyal a település átmeneti, illetve kései periódusa után létesültek. Elhelyezkedésük, valamint négyszögletes területeket elkerítő alakjuk alapján feltehetően határoló szerepet töltöttek be. A többi árokkal kapcsolatban csak relatív időrendet állapíthatunk meg. Így a településrészlet északkeleti részén található O-128 S-170es árkot vágja az O-127 S-169, O-163 S-223 és az O-134 S-181, illetve az O-135 S-183 árok, amelyek a 40. házon is keresztülfutnak, míg az O-126 S-168-as árkot az O-141 S-191-es árok metszi. Elhelyezkedése alapján feltételezhetjük, hogy az O-149 S-203-as, illetve S-404-es árok egy időben létezett, vagy legalábbis összefüggésben lehetett az 1. karámmal. A falurészlet északi részén húzódó északnyugat-délkeleti irányú árkok, amelyek déli vége egy vonalban található a 2 . karám nyugati és keleti, valamint az 1 . karám nyugati oldalaival, helyzetük alapján eredetileg a 2. karámhoz csatlakozhattak. A település centrumának nyugati részén, a 2. karám nyugati oldalánál tapasztalható „szuperpozíció-halmaz” rendkívül összetett. Itt valószínúleg egy másik karám vagy valamilyen egyéb elkerített terület többszörös árokrendszere kapcsolódhatott a 2. karámhoz, ezáltal vágva - többek között - a 30. házat. Ahogy az a fentiek és a felszínrajz alapján látható, a jászfényszarui településen igen bonyolult árokrendszerek és szuperpozíciók figyelhetők meg, ezért a további árkok pontosabb keltezése egyelőre nem lehetséges. Az azonban már most kijelenthető, hogy az árkok, árokrendszerek túlnyomó többsége a település legkésőbbi periódusához vagy az azt követő időszakhoz köthető.

\section{Karámok}

A Szőlők alján feltárt Árpád-kori település centrumának északi szélén két karámként értelmezhető, négyszögletes területet körülölelő, többszörös árokrendszer látott napvilágot. Nem kizárt, hogy több árokrendszer is hasonló célt szolgált, de itt most csak a biztosan karámként értelmezhető objektumokat mutatom be. Az 1. karám belterülete 21×21-22 m, azaz 441-462 m², míg a 2 . karámé 15-17,5×27 m, tehát kb. 405-472 m² lehetett (8. kép). Az 1. karám többszörös kerítőárkának szélessége 2 és 3 méter, míg a 2. karámé 1,4 és 6 méter között változott. Az 1. karám bejárata a délkeleti sarokban lehetett, ugyanakkor az északi oldalán bizonytalanul megfigyelt, egymással párhuzamos árkok is utalhatnak egy bejárati részre. Az avar kori karámoknál szintén megfigyelhető olykor a tölcséresen szúkülő bejárat kialakítása, hogy ezzel is elősegítsék az állatok beterelését. ${ }^{82} \mathrm{~A} 2$. karám bejárata egyértelmúen látható az északkeleti sarokban. Az itt található oszlophely az egykori kapuhoz tartozhatott. A karámok területének mérete alapján valószínúleg nagyobb állatok, talán lovak vagy szarvasmarhák tartására használhatták ezeket. ${ }^{83}$ A karámok koráról annyit tudunk, hogy az 1. karám valamivel elóbb készülhetett, mint a 2., mivel az előbbit metszi az utóbbi. Mindkét árokrendszer betöltéséből késő Árpád-kori edénytöredékek kerültek elő, tehát a település kései periódusában vagy azt követóen lehettek használatban ezek a karámok. A többszörös árkokkal kapcsolatban korábban az is felmerült, hogy esetleg megújították az egyes árkokat, ${ }^{84}$ itt azonban semmi nem utalt erre. Ezzel az objektumtípussal Laszlovszky József foglalkozott először behatóbban. ${ }^{85}$ Azóta már több avar és Árpád-kori lelőhelyről is ismerünk a jászfényszaruihoz hasonló, négyszögletes karámokat, de több helyen kerek vagy ovális formájú típusaik is megfigyelhetők voltak. ${ }^{86}$ Kör alakú avar kori karámok ismertek többek között Szedres-Apáti-pusztáról, ${ }^{87}$ valamint különböző formájú Árpád-koriakról van adatunk például az M0-ás autópálya nyomvonalán feltárt lelóhe-

\footnotetext{
82 SzABÓ 2012, 83

$83 \mathrm{Az}$ archeozoológiai leletek feldolgozása még nem kezdődött el, így a helyi állattartásra vonatkozó pontos adatok jelenleg hiányoznak.

84 VÁlyi 2003, 33; SZABÓ 2012, 79.

85 LASZLOVSZKY 1982.

86 Pl. Pácin-Alharaszt (RINGER-SZÖRÉNYI 2011, 508).

87 SZABÓ 2012, 64-66.
} 
lyekről, ${ }^{88}$ Ménfócsanak-Szeles-dúlőről, ${ }^{89}$ Kistelekről (több lelőhelyről) ${ }^{90}$ és Tatabányáról. ${ }^{91}$

\section{Tárolóvermek}

Jelen dolgozat keretében nem kívánom bemutatni az Árpád-kori falu valamennyi vermét. A 28, településszerkezet szempontjából is érdekes, házak környezetében található, többnyire szabályos kör vagy négyszögletes formájú verem közül összesen 11 tartalmazott régészeti leletanyagot, de többnyire ez is csupán néhány kerámiatöredéket jelentett. A jelenség arra utalhat, hogy ezek a vermek élelemtárolásra szolgáltak, és később sem használták őket túl gyakran hulladékgyújtésre. A tárolóvermek egyszerre csak egyféle élelmiszer elhelyezésére adtak lehetóséget, így nem meglepő, ha egy-egy épület körül többet is találunk. ${ }^{92}$ A vermekból származó leletek két objektumot leszámítva mind a késő Árpád-korra, tehát a település kései periódusára keltezhetők. A leletszegénység és a kései töredékek dominanciája alapján feltételezhetó, hogy a késó Árpád-kori cserepek csak a használatot követő betemetés/betemetődés során kerültek a vermekbe. Tehát a házak környezetében lévő vermek kronológiailag nem köthetók egy-egy épülethez, így nem lehet összekapcsolni az egyegy gazdasági egységet alkotó településobjektumokat. Csupán egyetlen esetben lehetett biztosan az adott épülethez kötni egy téglalap alakú verem használatát. A korai periódusra keltezhetó a 18. ház déli oldalával párhuzamosan elhelyezkedő, S-139-es, 1,8×1,05 m méretú, (a nyesett felszíntől számítva) $22 \mathrm{~cm}$ mélységú, négyszögletes verem, újkori nevén "gödörpince". ${ }^{93}$ Méretei, egyenes alja, illetve leletmentessége is arra utal, hogy tárolásra használhatták, nagysága alapján azonban szinte már egy kezdetleges pince vagy tárolóhelyiség is lehetett volna. Hasonló kora középkori és Ârpád-kori telepjelenségekról több adat is található a szakirodalomban. ${ }^{94}$

\section{Kültéri kemencék}

A településszerkezet szempontjából még a kültéri kemencéket kell megemlíteni, amelyekből

\footnotetext{
88 RÁCZ 2014, 169-170

89 TAKÁCS 1996, 204.

90 VÁLyi 2003, 33-37.

91 VÉKONY 1980, 29.

2 BÉRES 1987, 29.

93 TAKÁCS 1996, 203.

94 MiChNAI 1981, 232; TAKÁCS 1993, 35; TAKÁCS 1996, 203 ; ŠALKOVSKÝ 2011, 436.
}

11 került elő Szólők alján. ${ }^{95}$ Erről az objektumtípusról Méri István közölt ma is érvényes megállapításokat. ${ }^{96}$ Azóta több kora középkori és Árpád-kori lelóhelyen is sikerült szabadtéri kemencéket feltárni, így többek között KarosMókahomokon (4), ${ }^{97}$ Karos-Tobolyka-dúlóben (12), ${ }^{98}$ Pácin-Alharaszton (19), ${ }^{99}$ illetve Hejőkeresztúron, ${ }^{100}$ de Felsőzsolcáról,101 Ménfőcsanakról és Lébényből is ismerünk hasonlókat. ${ }^{102} \mathrm{~A}$ jászfényszarui kültéri kemencék közül kettő nem tartalmazott leletet (2. és 11.), egy pedig a kései periódusra keltezhetó (8.); az öszszes többiből kora Árpád-kori leletanyag került elő. A leletanyaggal rendelkező szabadtéri kemencékben is csak néhány kerámiatöredéket lehetett találni. A 3., 6., 7. és 8. kültéri kemencéket - mondhatni idó- és energiatakarékosan - korábbi épületekben hozták létre. ${ }^{103} \mathrm{Ez}$ a megoldás segitheti a leletanyaggal nem rendelkező épületek keltezését. Így a korai leletanyagot tartalmazó 3., 6. és 7. kültéri kemencék csak a település legkorábbi időszakából származó házakat vághattak, tehát az általuk érintett 31., 13. és 10. házak a falu életének kezdetére tehetők. A kései leletanyagot tartalmazó 8 . szabadtéri kemence a 34 . házat metszette, tehát ez az épület legkésőbb az átmeneti időszakban lehetett használatban. A további hét kültéri kemence közül csak az 1., 10. és 4. kemencék álltak teljesen önmagukban. A 9., 11. és 5. szabadtéri kemencék más objektumokkal voltak szuperpozícióban, míg a 2. kemencének jóformán csak a nyomát lehetett megfigyelni. A jobban megmaradt objektumok között a legkisebb (1.) $60 \times 50 \mathrm{~cm}$, míg a legnagyobb (9.) $3,2 \times 1,7 \mathrm{~m}$ nagyságú. A nyesett felszíntól mért mélységük 10 és $100 \mathrm{~cm}$ között változik. Formájukat tekintve az 1., 5., 6., 9. és 10. szabadtéri kemencék az aknakemencék csoportjába sorolhatók. ${ }^{104}$ A 10 . kemence lejárata lépcsős kialakítású. A 3. kültéri kemencénél nagyméretú hamusgödröt ástak, és egy oszlophely is megfigyelhetó, ami tetó meglétére utalhat (6. kép 3). Valamilyen tetót emelhettek a kültéri kemencék előtere fölé, hogy ezzel

\footnotetext{
95 A kemencék a könnyebb kezelhetőség érdekében kaptak sorszámot. Objektum- és stratigráfiai számuk a következő: 1: O-143 S-195; 2: O-146 S-198; 3: O-160 S-220; 4: O-196 S-274; 5: O-226 S-314; 6: O-236 S-334+335; 7: O-232 S-326; 8: O-131 S-200; 9: O-94 S-118; 10: O-70 S-85.

96 MÉrI 1963.

97 RINGER-SZÖRÉNYI 2011, 501.

98 RINGER-SZÖRÉNYI 2011, 502.

99 RINGER-SZÖRÉNYI 2011, 505.

100 Wolf 1999, 169.

101 SIMONYI 2003, 125.

102 TAKÁCS 1996, 202-203.

103 MÉRI 1963, 273.

104 TAKÁCS 1993, 36.
} 

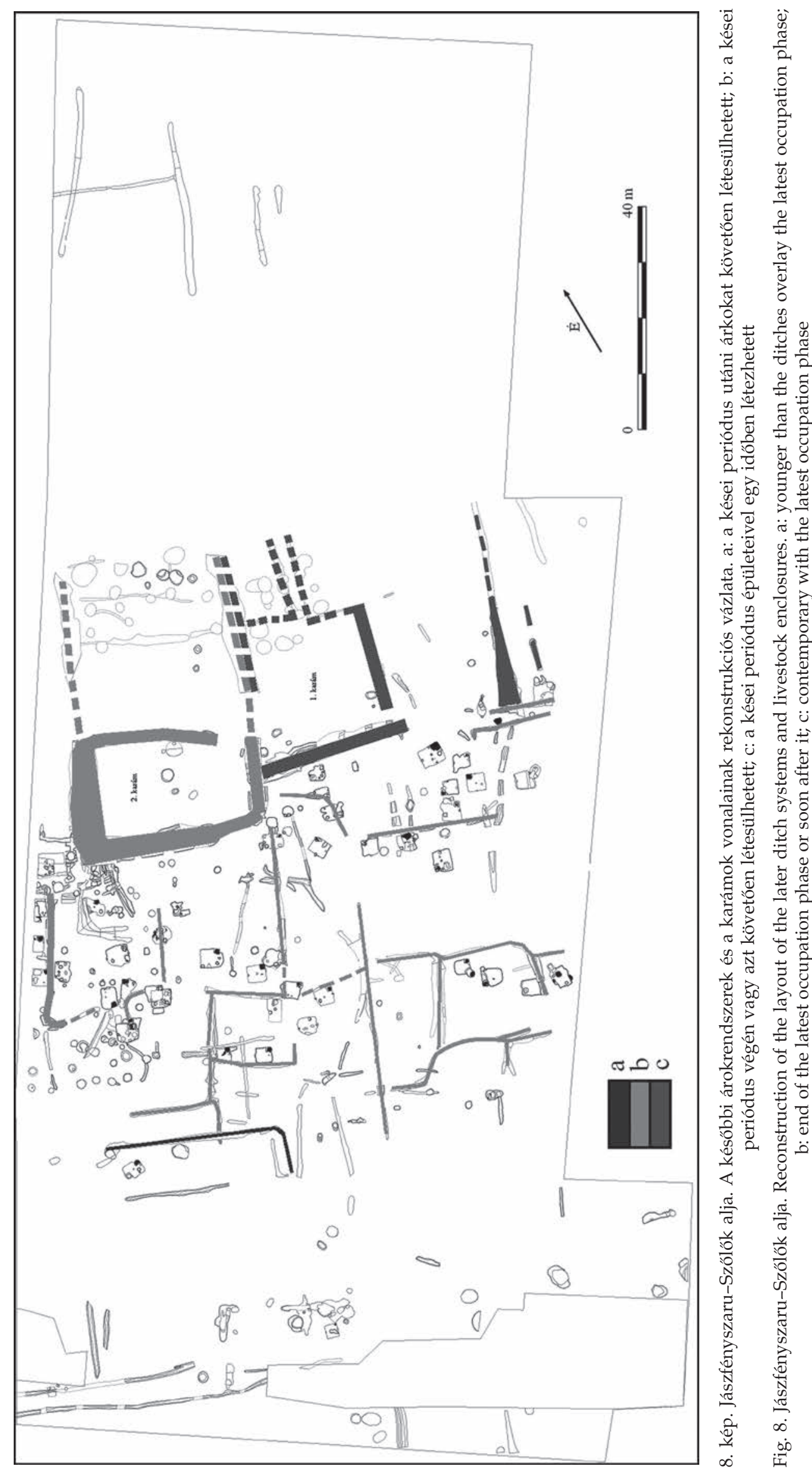
védjék az ott dolgozó embereket és magát a kemencét az idójárás viszontagságaitól. ${ }^{105}$ A 18 korai épületre elvileg 8 szabadtéri kemence jutott, tehát valószínúleg legalább két háztartás használt egy-egy kültéri kemencét, amelyek nem ipari felhasználásra szolgáltak, inkább az élelmiszerek tartósítására, füstölésre és pörkölésre, illetve sütésre voltak alkalmasak. ${ }^{106}$ Ezek az objektumok nem a település központjában, hanem többnyire a szélső lakóépületek környékén, illetve a centrum árkokkal szabdalt déli perifériáján kaptak helyet. Más településeknél is többnyire a falu két szélén helyezkedtek el. ${ }^{107}$ Ennek fényében a feltárás területének keleti részén található kültéri kemencék (összesen 8) talán már a település határának közelségét jelzik.

\section{A késóbbi árokrendszerek kérdése - a település további élete}

Az Árpád-kori falut felülrétegezte egy újfajta települési struktúra, amelynek fontos elemei voltak az árokrendszerek és az általuk határolt területek. A fent már részletesebben tárgyalt, az Árpád-kori falu kései épületeit (is) metsző árokrendszerek több esetben négyszögletes területeket kerítenek, így nagy valószínúséggel területhatároló funkciót töltöttek be (8. kép). Éppen azért, mert esetenként a késői periódus (12-13. század-14. század) házait is vágják, felmerül a kérdés, hogy mégis kik használták ezeket az árkokat, illetve pontosan milyen célt szolgáltak. A kérdésre két válaszlehetőség kínálkozik.

Az északnyugat-délkeleti irányú utca déli oldalán rajzolódnak ki a legjobban az árkok, olykor többszörös árkok által kerített négyszögek, amelyek alapterülete $11,5 \times 14,7 \mathrm{~m}, 11,2 \times 22,8 \mathrm{~m}$ és 16,2×16,9 m körüli (8. kép). E négyszögletes területek északi határa jól láthatóan követi az utca szélét, csak az O-175 S-239 és az annál korábbi O-219 S-301, 302, illetve utóbbi folytatása, az S-127 nyúlik bele az utcasávba. Az utca mentén egymás mellett sorakozó, nagyjából szabályos, négyszögletes területek alapján okkal feltételezhető, hogy ezek esetleg kerítésekkel határolt porták voltak, amelyekhez hasonlókat Rákospalota-Újmajor lelőhelyről ismerünk. ${ }^{108}$ Ebben az esetben tehát szabályos telekrendszerrel számolhatunk, amelyhez feltehetően felszíni épületek tartoztak. Ennek némiképp ellentmondani

\footnotetext{
105 MÉRI 1963, 275.

106 MÉRI 1952, 60; MÉRI 1963, 279.

107 Méri 1963, 279.

108 BENCZE 1999, 23.
}

látszik, hogy az említett O-175 S-239 árok amely a 8. háznál megfigyelt elágazása alapján minden bizonnyal a déli részen húzódó, négyszögletes területeket kerítő árokrendszerhez tartozott - belenyúlik az utcasávba, tehát nem igazodik hozzá.

A portahatárok mellett egy másik értelmezési lehetôség is felmerül, miszerint ezek az árokkomplexumok a korábban említettekhez hasonló, de azoknál valamivel kisebb méretú karámok lehettek. Ebben az esetben viszont kérdéses, hogy kik használták állataik kordában tartására ezeket az építményeket. Az Árpád-kori falu lakóinak későbbi tevékenységét vagy egy újabb népesség területfoglalását láthatjuk a négyszögletes területeket ölelő árokrendszerekben? A lelőhely korából és földrajzi elhelyezkedéséből adódóan ugyanis egy újabb problémakörrel is számolni kell: a jász beköltözéssel.

A település még megélte a 14 . század elejét, így felmerül a kérdés, hogy milyen kapcsolatban állt az újonnan érkező szomszédság az itt élő emberekkel, illetve a később hátrahagyott településsel. Jászfényszaru határában a beköltözó jászok a tatárjárás előtti településektől távolabb alakították ki szálláshelyüket, ${ }^{109}$ de nem kizárt, hogy az új lakók hasznosították a szállásukhoz közeli, elnéptelenedett területet.

A jászok betelepedésének ideje és mikéntje vitatott. Azonban már hosszú évtizedek óta „rögzült" a kutatásban az a nézet, amely szerint a jászok a kunokkal együtt, feltehetően azok segédnépeként költöztek be a középkori magyar állam területére. ${ }^{110}$ Selmeczi László is ezt a feltevést erősítette meg feltárásainak eredményeivel, ${ }^{111}$ valamint a történeti adatok alapján is ez túnik a legelfogadhatóbbnak, ${ }^{112}$ így a 13. század második felében talán már számolhatunk a jászok jászsági jelenlétével. ${ }^{113}$ Ezt az elméletet az írott források hiánya kérdőjelezheti meg, mivel azok csupán a 14. század első harmadától szolgálnak némi információval a jászokról. Györffy György az érintett birtokok tulajdonjogára hivatkozva látta kétségesnek a beköltözés 13. századi időpontját. ${ }^{114}$ Kristó Gyula a 14. század első két év-

\footnotetext{
109 SELMECZI 2001, 139.

110 SZABÓ 1979, 26; KÓSA-FILEP 1983, 121; TÓTH-TÓTH 1988, 175 ; SELMECZI 1996, 69; Zsoldos 1997, 175; H. BATHÓ 2000, 259; LANGÓ 2000, 99; LANGÓ 2001a, 161-163; LANGÓ 2001b, 163170; BÁNKINÉ MolnÁR 2005, 17; SELMECZi 2005a, 47; SELMECZI 2005b, 83; LANGÓ 2006, 90; SZENDE 2000, 111; SELMECZI 2011, 66; SELMECZI 2013, 16; PÁlÓCZI HoRVÁtH 2014, 195.

111 SELMECZI 1981; SELMECZI 1992, 103-104, 147.

112 LANGÓ 2001b, 163-170.

113 LANGÓ 2006, 83; PÁLÓCZI HorvÁth 2014, 195.

114 GYÖRFFY 1990, 314.
} 
tizedére tette a jászok megjelenését, ${ }^{115}$ újabban pedig Tóth Péter is a késóbbi beköltözés mellett foglalt állást. ${ }^{116} \mathrm{~A}$ vita tehát még ma sem tekinthető lezártnak. A mi szempontunkból mindenképpen fennáll annak lehetósége, hogy a Szőlők alján feltárt település lakói még éppen találkoztak a jászokkal, vagy nem sokkal érkezésük előtt hagyták el településüket, mivel a 14. század elején még létezett a falu. Jászfényszaru határában a jászok 14. századi jelenlétére utal a dolgozat elején már említett Kozma-dombi lelőhely, amelyet Selmeczi László Kozmadamjánszállással azonosít. ${ }^{117} \mathrm{Az}$ itt feltárt, éremmel keltezett sírok egyértelmúen a 15. századra tehetők, azonban néhány temetkezés kapcsán (pl. 3. sír) elképzelhetó, hogy az elhunytat még a 14. század folyamán helyezték örök nyugalomra. ${ }^{118}$

\section{Összefoglalás}

Jászfényszaru-Szőlők alján egy viszonylag nagy kiterjedésú és hosszú életú Arpád-kori falut sikerült feltárni. A mocsarasabb területból kiemelkedő homokháton álló, különböző mértékben földbe mélyített házak és a feltételezhető felszíni épületek több évszázadon át megfelelő lakóhelyet biztosítottak az embereknek. A település struktúrájának kialakításában szerepet játszottak bizonyos rendezési elvek, amelyek alapján utcát, házsorokat, telkeket alakítottak ki. A falu lakói úgy osztották fel egymás között a területet, hogy ez a felosztás több generáción át is fennmaradhatott, ahogyan erre a korábbi, elpusztult vagy lebontott házak helyén létesített újabb épületek is utalnak. Néhány esetben a házak gödréból származó betöltés hamus, szenes, törmelékes összetétele alapján az adott épület leégésére következtethetünk, azonban nem figyelhető meg egy egységes pusztulási réteg, illetve más sem utal arra, hogy menekülésszerúen hagyták volna hátra a falut. A leletanyag jelentős része kerámiatöredék. Ép, valamint kiegészíthető edény is csak egy-egy példány került elö, a fémtárgyak pedig csak elvétve jelennek meg a leletanyagban. Mindez a település tervszerú kiürítésére utal. A házak más lelőhelyeken tapasztaltakhoz hasonló, ${ }^{119}$ szegényes leletegyüttese alapján amely szándékosan hátrahagyott, használatra már nem alkalmas tárgyakból állt - nem következtethetünk az itteni lakosok társadalmi hovatartozására. A település földrajzi elhelyezkedése, valamint több évszázadot felölelő élete mindenképpen fontos alapot nyújt a további kutatáshoz a jász beköltözés, illetve a településhálózat tekintetében.

\section{IRODALOM}

BAGI GÁBOR

1993 Katonáskodás, katonai szolgálat a magyarországi jászoknál a XIII-XIX. században. Tisicum (Szolnok) 8, 247-268.

BÁNKINÉ MolNÁR ERZSÉBET

2005 A jászkun autonómia. Dél-alföldi Évszázadok 22. Szeged.

H. BATHÓ EDIT

2000 Adatok a Jászság XIII-XX. századi viseletéhez. In: Langó P. (szerk.): Szállástól a mezővárosig. Tanulmányok Jászfényszaru és a Jászság múltjából. Jászfényszaru, 259-287.

BELUSZKY PÁL

2001 A Nagyalföld történeti földrajza. Dialóg Campus Szakkönyvek - Dialóg Campus Tankönyvek. Budapest-Pécs.

BENCZE ZOLTÁN

1999 Beszámoló a Rákospalota-Újmajor területén 1995-1997 között folytatott feltárások középkori eredményeiről (Bericht über die mittelalterlichen Ergebnisse der archäologischen Ausgrabungen durchgeführt 1995-1997). In: Bencze Z.-Gyulai F.-Sabján T.-Takács M.: Egy Árpád-kori veremház feltárása és rekonstrukciója. Monumenta Historica Budapestinensia X. Budapest, 9-72.

115 KRISTÓ 2003, 233-243.

116 TóтH 2013, 9-22. Egyes kutatók, így Gyárfás István és Langó Péter újabb jász beköltözést is valószínúsítenek az 1365. évre (GYÁRFÁs 1883, 45; LANGÓ 2003, 47). Ekkor Nagy Lajos hadjárata során elfoglalta Vidint, ahol jászok is harcoltak ellenük. Közülük többeket foglyul ejtettek, és a király Kont Miklós nádornak adományozta őket (TóTH 2013, 40-41; LANGó 2000, 99). Ez a jász csoport feltehetően beolvadt Kont Miklósék, többi jobbágya közé, így nem valószínú, hogy a mai Jászság lakóinak az őseit kereshetnénk bennük (То́тн 2013, 40-41). Bagi Gábor szerint végül ők is a Jászságban telepedtek le (BAGI 1993, 249).

117 SeLMECZI 2001, 127-129.

118 SELMECZI 2001, 136.

119 RÁCZ 2013, 43. 
BENEDEK Gyula-ZÁdorné Zsoldos MÁRIA

1998 Jász-Nagykun-Szolnok megyei oklevelek 1075-1526. Jász-Nagykun-Szolnok Megyei Levéltár Közleményei 3. Szolnok.

BÉRES MÁRIA

1987 Adatok az Árpád-kori gabonatárolás kérdéséhez (Beiträge zur Getreidespeicherung in der Arpadenzeit). BÍRÓ GYÖNGYVÉR Móra Ferenc Múzeum Évkönyve (Szeged) 1, 25-35.

2013a Árpád-kori teleprészlet Jászfényszaru-Szőlők-alján (Part of a settlement from the Árpádian Age in Jászfényszaru-Szőlők-alja). In: Pintér-Nagy K.-Takács M. (szerk.): Acta Universitatis Szegediensis. Acta Iuvenum Sectio Archaeologica. Tomus I. Szeged, 144-171.

2013b Természettudományos vizsgálatok használata az Árpád-kori falukutatásban. Szakdolgozat. Szegedi Tudományegyetem, Szeged.

2014 Többrétegú Ấrpád-kori település Jászfényszaru-Szőlők-alján (Multi-layered Árpád age settlement at Jászfényszaru-Szőlők-alja). In: Rácz T. Á. (szerk.): A múltnak kútja. Fiatal középkoros régészek V. konferenciájának tanulmánykötete (The Fountain of the Past. Study Volume of the Fifth Annual Conference of Young Medieval Archaeologists). Szentendre, 113-131, 385-397, 454.

2015 Árpád-kori fenékbélyeges kerámiák Jászfényszaru-Szőlők alján. Észrevételek a fenékbélyeges edények kérdéséhez. In: Szőllősy Cs.-Pokrovenszki K. (szerk.): Fiatal középkoros régészek VI. konferenciájának tanulmánykötete. Megjelenés alatt.

BíRÓ GYÖNGYvÉR-FINTOR KRISZTIÁN-RAUCSIK BÉLA-WOLF MÁRIA-TÓTH MÁRIA

2013 Jászfényszaru-Szőlők-alja lelőhelyről származó Árpád-kori kerámiák archeometriai vizsgálata. Archeometriai Múhely (Budapest) 2014/XI./1, 27-38.

BÓNA ISTVÁN

1973 VII. századi avar települések és Árpád-kori magyar falu Dunaújvárosban (7th-century Avar settlements and a village of Arpadian-age Hungarians in Dunaújváros). Fontes Archaeologici Hungariae. Budapest.

FODOR FERENC

1942 A Jászság életrajza. Budapest.

GALLINA ZsOLT-GULYÁs GYÖNGYI-MOLNÁR IsTVÁN

2014 Késő Árpád-kori településrészlet Kiskunfélegyháza, Amler-bányából. In: Somogyvári Á.-Szentpéteri J.V. Székely Gy. (szerk.): Településtörténeti kutatások. Solt-Tételhegy, Kiskunfélegyháza-Amler-bánya (Settlement Studies. Solt-Tételhegy, Kiskunfélegyháza, Amler-bánya). Archaeologia Cumanica (Kecskemét) 3, 275-380.

GALLINA ZSOLT-MOLNÁR ISTVÁN

2004 Épületek és szerkezeti elemeik egy késő Árpád-kori településen (Kiskunfélegyháza-Amler-bánya, Déli összekötő híd) (Gebäude und ihre Konstruktionselemente in einer spätarpadenzeitlichen Siedlung (Kiskunfélegyháza-Amler-Grube, südliche Verbindungsbrücke). A Móra Ferenc Múzeum Évkönyve Studia Archaeologica (Szeged) 10, 525-552.

GULYÁs GYÖNGYI

2007 Egy elpusztult falu Cegléd határában (Pest m.). In: Ritoók Á.-Garam É. (szerk.): A tatárjárás. Budapest, 52-53.

2014 Egy elpusztult tatárjárás kori ház Cegléd határában. In: Rosta Sz.-V. Székely Gy. (szerk.): „Carmen Miserabile”. A tatárjárás magyarországi emlékei. Tanulmányok Pálóczi Horváth András 70. születésnapja tiszteletére. Kecskemét, 29-56.

GYÁRFÁs ISTVÁN

1883 A Jász-kunok története. III. kötet. Kecskemét-Szolnok.

GYÖRFFY GYÖRGY

1990 A magyarság keleti elemei. Budapest.

ÍrÁSNÉ MELIS KATALIN

1992 Árpád-kori falvak Szigetszentmiklós határában (Arpadenzeitliche Dörfer in der Gemarkung von Szigetszentmiklós). In: Havassy P.-Selmeczi L. (szerk.): Régészeti kutatások az M0 autópálya nyomvonalán 2. BTM Múhely 6. Budapest, 41-70.

KÓSA LÁSZLÓ-FILEP ANTAL

1983 A magyar nép táji-történeti tagolódása. Budapest.

KovALOVSZKi JÚLIA

1980 Településásatások Tiszaeszlár-Bashalmon (Bronzkor, III-IV. és XI-XIII. század) (Siedlungsgrabungen in Tiszaeszlár-Bashalom). Fontes Archaeologici Hungariae. Budapest.

KRISTÓ GYULA

2003 Nem magyar népek a középkori Magyarországon. Budapest. 
LANGÓ PÉTER

2000 A jászok etnogenezise és korai történetük. In: Langó P. (szerk.): Szállástól a mezővárosig. Tanulmányok Jászfényszaru és a Jászság múltjából. Jászfényszaru, 83-109.

2001a A jászok korai történetének megítélése a 19-20. században. A Jász Múzeum Évkönyve (Jászberény) 1975-2000, 151-176.

2001b Jászok a középkori Pilis megyében. Limes: tudományos szemle (Tatabánya) 1-2, 121-134.

2003 Ladány, Varsány, Oszlár. Keleti néptöredékek és a korai helynevek kapcsolata. Limes: tudományos szemle (Tatabánya) 3, 39-54.

2006 Régészeti és okleveles adatok a Jászság 10-15. századi településtörténetéhez (Archaeological and Charter Data for the Jazygian Settlemental History in the 10th-15th Centuries). Tisicum (Szolnok) 15, 77-97.

LASZLOVSZKY JÓZSEF

1982 Karámok Árpád-kori falvainkban (Pferche in unseren arpadenzeitlichen Dörfern). Archaeologiai Értesító (Budapest) 109, 281-285.

1991 Árpád-kori és késő középkori objektumok. In: Tálas L.-Madaras L. (szerk.): Régészeti ásatások Tiszafüred-Morotvaparton. Szolnok Megyei Múzeumi Adattár 32. Szolnok, 317-384.

\section{LUKÁCS NiKOLETTA}

2014 Kora középkori településrészlet Orosháza határában (Early Medieval Settlement Fragment at the Borders of Orosháza). In: Rácz T. Á. (szerk.): A múltnak kútja. Fiatal középkoros régészek V. konferenciájának tanulmánykötete (The Fountain of the Past. Study Volume of the Fifth Annual Conference of Young Medieval Archaeologists). Szentendre, 99-111.

MAKSAY FERENC

1971 A magyar falu középkori településrendje. Budapest.

MÉRI ISTVÁN

1952 Beszámoló a Tiszalök-rázompusztai és Túrkeve-mórici ásatások eredményéről I. (Bericht über die Resultate der Ausgrabungen von Tiszalök-Rázompuszta und Túrkeve-Móric I). Archaeologiai Értesítő (Budapest) 79, 49-67.

1962 Az árkok szerepe Árpád-kori falvainkban (Angaben zur Siedlungsform der arpadenzeitlichen ungarischen Dörfer). Archaeologiai Értesítő (Budapest) 89, 211-218.

1963 Árpád-kori szabadban lévő kemencék (Freistehende Backöfen aus der Regierungszeit des Hauses Árpád, 10.-13. Jh.). Archaeologiai Értesítő (Budapest) 90, 273-280.

Mesterházy KÁROLY-HoRvÁth Lajos

1983 Településtörténeti kutatások Veresegyház határában (Siedlungsgeschichtliche Forschungen in der Michnai Attila Gemarkung von Veresegyház). Archaeologiai Értesítő (Budapest) 110, 112-125.

1981 Középkori népi építészetünk régészeti emlékei (Archäologische Denkmäler der mittelalterlichen volkstümlichen Baukunst Ungarns). Folia Archaeologica (Budapest) 32, 225-240.

PÁlócZi HorVÁTH ANDRÁs

2014 Keleti népek a középkori Magyarországon. Besenyők, úzok, kunok és jászok múvelődéstörténeti emléRÁCZ TiBOr ÁkOs kei. In: Major B.-Türk A. (szerk.): Studia ad Archaeologiam Pazmaniensiae. Budapest-Piliscsaba.

2010 Árpád-kori települések szerkezetének sajátosságai Pest megyében. Kutatások az M0-s autópálya és a 4-es elkerülő fóút nyomvonalán (Characteristics of the Structure of Árpádian-era Settlements. Investigations Along the Line Followed by the M0 Motorway and the Highway 4 Bypass). In: Benkő E.Kovács Gy. (szerk.): A középkor és a kora újkor régészete Magyarországon I. Budapest, 69-79.

2013 Társadalmi különbségek a Magyar Királyság központi területeinek 10-14. századi falusisas településein. In: Varga M. (szerk.): Fiatal Középkoros Régészek IV. Konferenciájának Tanulmánykötete. A kaposvári Rippl-Rónai Múzeum Közleményei (Kaposvár) 2, 41-52.

2014 Árpád-kori lakóépítmények az M0-s autópálya nyomvonalán. Szempontok a veremházak rendszerezéséhez. (Arpad Age Dwelling Structures along the Track of the Highway M0; Viewpoints to the Classification of Pit Houses). In: Rácz T. Á. (szerk.): A múltnak kútja. Fiatal középkoros régészek V. konferenciájának tanulmánykötete (The Fountain of the Past. Study Volume of the Fifth Annual Conference of Young Medieval Archaeologists). Szentendre, 145-176.

RINGER ISTVÁN-SZÖRÉNYI GÁBOR ANDRÁS

2011 Árpád-kori település feltárása Pácin határában. In: Kolozsi B.-Szilágy K. A. (szerk.): Sötét idők falvai. 2006-ban Debrecenben megrendezett konferencia 2. kötete. Debrecen, 499-517.

SABJÁN TiBOR

1999 A veremház rekonstrukciója. In: Bencze Z.-Gyulai F.-Sabján T.-Takács M.: Egy Árpád-kori veremház feltárása és rekonstrukciója (Die Rekonstruktion des Grubenhauses). Monumenta Historica Budapestinensia 10. Budapest, 131-176. 
ŠALKOVSKÝ, PETER

2001 Häuser in der frühmittelalterlichen slawischen Welt. Archaeologica Slovaca Monographiae. Studia Instituti Archaeologici Nitriensis Academiae Scientiarum Slovacae, Tomus VI. Nitra.

2011 Das frühmittelalterliche Dorf im Karpatenbecken. In: Kolozsi B.-Szilágy K. A. (szerk.): Sötét idők falvai. 2006-ban Debrecenben megrendezett konferencia 2. kötete. Debrecen, 419-450.

SELMECZI LÁSZLÓ

1981 A négyszállási jász temető. Előzetes közlés az 1980. évi feltárásról (Der Friedhof der Jassen von Négyszállás). Communicationes Archaeologicae Hungariae (Budapest), 95-109.

1992 Régészeti-néprajzi tanulmányok a jászokról és a kunokról. Folklór és etnográfia 64. Debrecen, 25-31.

1996 A jászok betelepülése a régészeti leletek tükrében. In: Havassy P. (szerk.): Zúduló sasok. Gyulai katalógusok 2. Gyula, 67-80.

2001 Egy eltúnt jász település nyomában (In the track of a disappeared Jazygian settlement). A Jász Múzeum Évkönyve (Jászberény) 1975-2000, 127-149.

2005a A jászok eredete és középkori múveltsége. Jászsági Füzetek 37. Jászberény.

2005b A jászok betelepedése Magyarországra. In: Bánkiné Molnár E. (szerk.): Jogszabályok - jogszokások. Jászkunság kutatása 2005. Kiskunfélegyháza, 27-60.

2011 A Jászság betelepedése és kialakulása. Zounuk (Szolnok) 26, 9-108.

2013 A jászok kutatásának néhány problémája. In: Mészáros M. (szerk.): Jászkunság kutatása 2012. Legújabb eredmények a Jászkunság régészeti, történeti, nyelvészeti és néprajzi kutatásában. Ünnepi konferenciakötet Selmeczi László 70. születésnapja tiszteletére. Kiskunfélegyháza, 16-28.

SIMONYI ERIKA

2003 Előzetes jelentés a Felsőzsolca-Várdombi ásatásról (1992-2001) (Report of the excavations at FelsőzsolcaVárdomb, 1992-2001). Herman Ottó Múzeum Évkönyve (Miskolc) 42, 109-133.

SZABÓ GÉZA

2012 Rejtélyes körárkok. Adatok az avar kori településszerkezethez. In: Liska A.-Szatmári I. (szerk.): Sötét idők rejtélyei. 6-11. századi régészeti emlékek a Kárpát-medencében és környékén. Békéscsaba, 63-91.

SZABÓ IsTVÁN

1969 A középkori magyar falu. Budapest.

SZABó LÁSZLÓ

1979 A jász etnikai csoport I. A jász etnikum és a jászsági múveltségi egység néprajza. Kandidátusi értekezés.

SZENDE LÁSZLÓ Szolnok.

2000 „... most pogányokkal védelmeztetjük országunkat” (A kunok és jászok katonai szerepe IV. Béla osztrák politikájában). In: Langó P. (szerk.): Szállástól a mezővárosig. Tanulmányok Jászfényszaru és a Jászság TAKÁCS MiKLÓs múltjából. Jászfényszaru, 111-130.

1993 Falusi lakóházak és egyéb építmények a Kisalföldön a 10-16. században (Kutatási eredmények és további feladatok). In: Perger Gy.-Cseri M. (szerk.): A Kisalföld népi építészete. Szentendre-Győr, 7-53.

1996 Honfoglalás és korai Árpád-kori telepfeltárások az M1 autópálya nyugat-magyarországi szakaszán. In: Wolf M.-Révész L. (szerk.): A magyar honfoglalás korának régészeti emlékei. Miskolc, 197-217.

2002 Der Hausbau in Ungarn vom 2. bis zum 13. Jahrhundert n. Chr. - Ein Zeitalter einheitlicher Grubenhäuser? / The houses of village-like settlements in Hungary of the $2^{\text {nd }}-13^{\text {th }}$ centuries A.D. - A

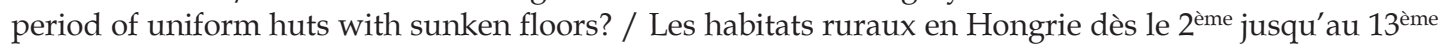
s. après J.-Ch. - Une période des maisons demi-creusées unifiées. Ruralia (Praha) 4, 272-290.

2010 Árpád-kori falusias települések kutatása Magyarországon 1990 és 2005 között (The Researching of Arpadian era [eleventh-thirteenth century] Village-like Settlements in Hungary between 1990 and 2005). In: Benkő E.-Kovács Gy. (szerk.): A középkor és a kora újkor régészete Magyarországon I. Budapest, $1-67$.

TEREI GYÖRGY

2010a Az Árpád-kori Kána falu feltárása. In: Tüskés A. (szerk.): Ars perennis. Fiatal Múvészettörténészek II. Konferenciája, Budapest, 2009. Budapest, 249-252.

2010b Az Árpád-kori Kána falu. Kána (A village from the Árpádian Era, twelfth-thirteenth centuries). In: Benkó E.-Kovács Gy. (szerk.): A középkor és a kora újkor régészete Magyarországon I. Budapest, 81-111.

Tóth JÁNOS-TÓTH MARIANNA

1988 A jászok őstörténete. In: Szombathy V.-László Gy. (szerk.): Magyarrá lett keleti népek. Budapest, 164175.

TÓTH PÉTER

2013 Tanulmányok a magyarországi jászok és a Jászság középkori történetéről. Kisebbségkutatás Könyvek. Budapest. 


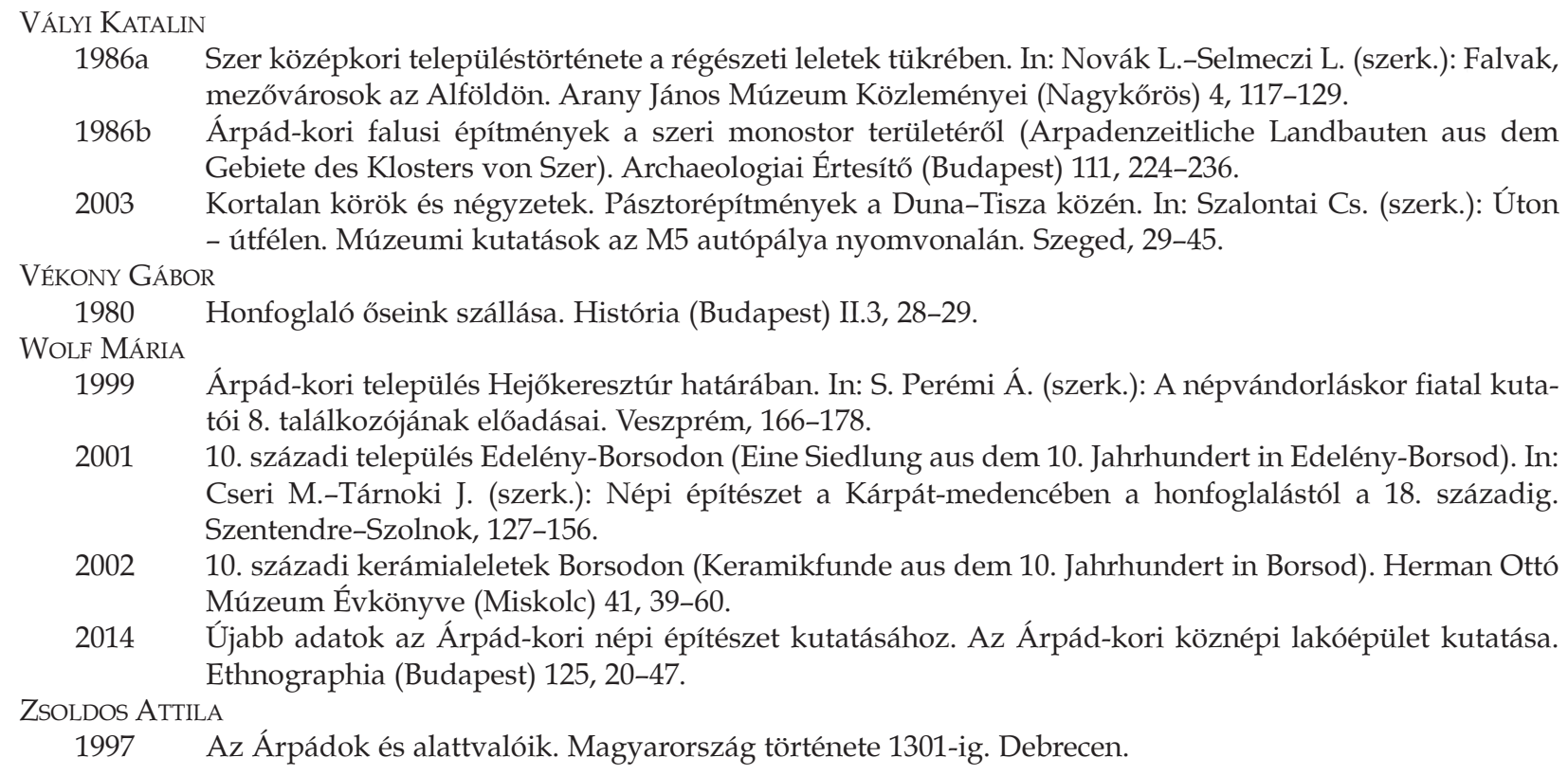

\section{THE BUILDINGS AND SETTLEMENT LAYOUT OF THE ÁRPÁDIAN AGE SETTLEMENT EXCAVATED AT JÁSZFÉNYSZARU-SZŐLŐK ALJA}

\section{GYÖNGYVÉR BíRÓ}

The excavation directed by Róbert Kertész was conducted by the staff of the Damjanich János Museum in 2007. Most of the archaeological finds came from an Árpádian Age settlement; however, several Sarmatian features as well as prehistoric ones were also uncovered. This paper presents the buildings of the Árpádian Age settlement, alongside the other major structures (ditches, livestock enclosures, open-air ovens) as well as the layout of the settlement.

The settlement had forty-four houses, eleven open-air ovens and two livestock enclosures as well as several pits and ditch systems. The finds were dominated by ceramics (mostly fragments, aside from two intact vessels); however, stone tools such as whetstones and grindstones, and animal bones also came to light. In contrast, the number of metal artefacts typically used in Árpádian Age villages was low. Only a single metal artefact with a dating value, a spur, was recovered from the building remains. Based on the superpositions of individual features and on the finds, several phases can be distinguished in the Árpádian Age occupation of the village. There was probably a transitional period between the early (11thlater 12th century) and the late (12th/13th century and early 14 th century) occupation. According to the written sources, life was continuous in the village.

The groundplan of the houses is usually rectangular or square with slight irregularities. Their longer side ranges between 2.5 and $4.6 \mathrm{~m}$ (with an average of $3.42 \mathrm{~m}$ ), while their shorter side is between 2.1 and $4.2 \mathrm{~m}$ (with an average of $2.91 \mathrm{~m}$ ). The longitudinal axis of the buildings is generally north-west to south-east oriented. Six types can be distinguished among the houses regarding their structure. 1. Two forked ridge poles on the short or the long side. 2. Three forked ridge poles along the central axis of the house. 3. One or two posts either on the shorter or on the longer side. 4 . One post in the middle. 5. Four posts in the middle of the sides and one in the middle of the house. 6 . Houses without posts. In the case of six buildings, different structural constructions could be identified. The existence of upright walls was indicated by house types 4-6 as well as the debris fill of the houses, which included daub fragments, even though no other finds evidenced their one-time presence. Step-like entrances were observed in seven houses: four of these lay in the south-western, two in the north-western and one in the south-eastern corner. The houses did not have a beaten clay floor, but merely a straight and even floor. With one exception, all the houses had sunken and clay-plastered ovens. The ovens inside the houses were usually round, the open-air ones were square.

We made a digital elevation model based on GIS data. The Árpádian Age village was located on a north-west to south-east oriented ridge rising above the surrounding waterlogged marshland. A 17-23 m wide, roughly $75 \mathrm{~m}$ long street ran down the middle of the settlement. Elements of a planned layout could be noted in the settlement's structure, reflected by the above-mentioned street and the rows of houses aligned to the street as well as the boundaries of the land plots. 
The excavated ditches often formed a complex and barely reconstructable system. Their practical purpose may have been the separation of plots, since most of them enclosed square areas. The ditch systems were usually earlier than the Árpádian Age houses.

Two livestock enclosures were excavated at Szőlők alja, with an area of $21 \mathrm{~m}$ by $22 \mathrm{~m}$ and $15-17.5 \mathrm{~m}$ by $22 \mathrm{~m}$, respectively. The boundaries of the livestock enclosures were marked by multiple ditches.

The pits found in close proximity to the Árpádian Age houses contained few finds; the pits could not be associated with particular buildings. These pits may have been used to store food. Four of the eleven open-air ovens were built in former house pits.
The later ditch systems may have accommodated the fences enclosing the plots belonging to the above-ground buildings or they may have been livestock enclosures. Since these ditches often cut across the houses of the later occupation phase and they do not always follow the line of the streets, we may assume that the area was utilised in some other manner during the 14th century: the Jász population settling in the area set up livestock enclosures in the depopulated area. Since finds from later periods were not excavated on the site, the time that elapsed between the houses of the later occupation period and the construction of the ditch systems cannot have been too long. 